\title{
Gas exchange during exercise in habitually active asthmatic subjects
}

H. C. Haverkamp, J. A. Dempsey, J. D. Miller, L. M. Romer, D. F. Pegelow, J. R. Rodman and M. W. Eldridge

Journal of Applied Physiology 99:1938-1950, 2005. First published Jul 14, 2005;

doi:10.1152/japplphysiol.00041.2005

You might find this additional information useful...

This article cites 56 articles, 30 of which you can access free at:

http://jap.physiology.org/cgi/content/full/99/5/1938\#BIBL

Updated information and services including high-resolution figures, can be found at: http://jap.physiology.org/cgi/content/full/99/5/1938

Additional material and information about Journal of Applied Physiology can be found at: http://www.the-aps.org/publications/jappl

This information is current as of October 16, 2005 .

\footnotetext{
Journal of Applied Physiology publishes original papers that deal with diverse areas of research in applied physiology, especially those papers emphasizing adaptive and integrative mechanisms. It is published 12 times a year (monthly) by the American

Physiological Society, 9650 Rockville Pike, Bethesda MD 20814-3991. Copyright @ 2005 by the American Physiological Society. ISSN: 8750-7587, ESSN: 1522-1601. Visit our website at http://www.the-aps.org/.
} 


\title{
Gas exchange during exercise in habitually active asthmatic subjects
}

\author{
H. C. Haverkamp, ${ }^{1}$ J. A. Dempsey, ${ }^{1}$ J. D. Miller ${ }^{1}$ L. M. Romer, ${ }^{1}$ \\ D. F. Pegelow, ${ }^{1}$ J. R. Rodman, ${ }^{1}$ and M. W. Eldridge ${ }^{1,2}$ \\ ${ }^{1}$ The John Rankin Laboratory of Pulmonary Medicine, Department of Population Health Sciences, \\ and ${ }^{2}$ Department of Pediatrics, University of Wisconsin-Madison, Madison, Wisconsin
}

Submitted 12 January 2005; accepted in final form 11 July 2005

Haverkamp, H. C., J. A. Dempsey, J. D. Miller, L. M. Romer, D. F. Pegelow, J. R. Rodman, and M. W. Eldridge. Gas exchange during exercise in habitually active asthmatic subjects. J Appl Physiol 99: 1938-1950, 2005. First published July 14, 2005; doi:10.1152/japplphysiol.00041.2005.-We determined the relations among gas exchange, breathing mechanics, and airway inflammation during moderate- to maximum-intensity exercise in asthmatic subjects. Twenty-one habitually active (48.2 \pm 7.0 $\mathrm{ml} \cdot \mathrm{kg}^{-1} \cdot \min ^{-1}$ maximal $\mathrm{O}_{2}$ uptake) mildly to moderately asthmatic subjects $(94 \pm 13 \%$ predicted forced expiratory volume in $1.0 \mathrm{~s})$ performed treadmill exercise to exhaustion $(11.2 \pm 0.15$ min) at $\sim 90 \%$ of maximal $\mathrm{O}_{2}$ uptake. Arterial $\mathrm{O}_{2}$ saturation decreased to $\leq 94 \%$ during the exercise in 8 of 21 subjects, in large part as a result of a decrease in arterial $\mathrm{Po}_{2}\left(\mathrm{~Pa}_{\mathrm{O}_{2}}\right)$ : from $93.0 \pm 7.7$ to $79.7 \pm 4.0$ Torr. A widened alveolar-to-arterial $\mathrm{Po}_{2}$ difference and the magnitude of the ventilatory response contributed approximately equally to the decrease in $\mathrm{Pa}_{\mathrm{O}_{2}}$ during exercise. Airflow limitation and airway inflammation at baseline did not correlate with exercise gas exchange, but an exercise-induced increase in sputum histamine levels correlated with exercise $\mathrm{Pa}_{\mathrm{O}_{2}}$ (negatively) and alveolar-to-arterial $\mathrm{PO}_{2}$ difference (positively). Mean pulmonary resistance was high during exercise $\left(3.4 \pm 1.2 \mathrm{cmH}_{2} \mathrm{O} \cdot 1^{-1} \cdot \mathrm{s}\right)$ and did not increase throughout exercise. Expiratory flow limitation occurred in 19 of 21 subjects, averaging $43 \pm 35 \%$ of tidal volume near end exercise, and end-expiratory lung volume rose progressively to $0.25 \pm 0.47$ liter greater than resting end-expiratory lung volume at exhaustion. These mechanical constraints to ventilation contributed to a heterogeneous and frequently insufficient ventilatory response; arterial $\mathrm{PCO}_{2}$ was 30-47 Torr at end exercise. Thus pulmonary gas exchange is impaired during highintensity exercise in a significant number of habitually active asthmatic subjects because of high airway resistance and, possibly, a deleterious effect of exercise-induced airway inflammation on gas exchange efficiency.

exercise-induced arterial hypoxemia; airway inflammation; exercise hyperventilation; induced sputum; prolonged exercise

FEW STUDIES HAVE EVALUATED gas exchange during exercise in asthmatic subjects $(5,12,19,20,24,35)$. Collectively, these studies lack generalizability and are difficult to interpret for a variety of reasons. First, characterization of the subjects' airway disease was incomplete and lacking in detail. Small subject numbers and the use of children as participants further confound the generalizability of previous studies to asthmatic subjects as a population. Importantly, the exercise protocols were either discontinuous or of relatively short duration (5-10 $\mathrm{min}$ ), and the exercise was generally performed at low metabolic rates $\left[<2.01 / \mathrm{min} \mathrm{O}_{2}\right.$ uptake $\left.\left(\dot{\mathrm{V}}_{2}\right)\right]$, which were not

Address for reprint requests and other correspondence: H. C. Haverkamp Vermont Lung Center, Univ. of Vermont, 149 Beaumont Ave., HSRF 226, Burlington, VT 05405 (E-mail: hans.haverkamp@med.uvm.edu). sufficient to stress the pulmonary system's capabilities for ventilation and gas exchange.

There are several reasons to suspect greater gas exchange disturbance during exercise in asthmatic than in healthy nonasthmatic subjects. It has been shown using the multiple inert gas elimination technique that alveolar ventilation-to-perfusion $\left(\dot{\mathrm{V}}_{\mathrm{A}} / \dot{\mathrm{Q}}\right)$ nonuniformity at rest is greater in even mildly to moderately asthmatic subjects than in healthy subjects; this often results in a considerably widened alveolar-to-arterial $\mathrm{PO}_{2}$ difference $\left(\mathrm{A}-\mathrm{aDO}_{2}\right)$ and, although less often, arterial hypoxemia (54). This gas exchange disturbance is thought to be primarily caused by an uneven distribution of alveolar ventilation $\left(\dot{\mathrm{V}}_{\mathrm{A}}\right)$ due to narrowed and obstructed airways (54). The airway narrowing is caused by a variety of factors that arise as a consequence of airway inflammatory mediator release, including bronchial smooth muscle contraction, mucosal edema and thickening of the airway wall, peribronchial fluid accumulation and "cuffing" of the small airways, and luminal mucus and liquid accumulation (9). Additionally, the increased airflow during exercise is thought to stimulate the release of inflammatory mediators (e.g., histamine and leukotrienes) from airway cells during or shortly after exercise in asthmatic subjects (6). Because the bronchial smooth muscle and the vascular effects of these mediators are responsible for the peripheral airway changes that likely contribute to gas exchange disturbance in asthmatic subjects, exercise may cause or exacerbate any impairment in gas exchange. Thus gas exchange during exercise in asthmatic subjects might be impaired because of airway dysfunction at rest or an airway inflammatory response caused by the exercise.

Airway resistance, which is often high in asthmatic subjects, increases the propensity for expiratory flow limitation (EFL) and dynamic hyperinflation during exercise in asthmatic compared with nonasthmatic subjects $(14,34,52)$. In healthy subjects, EFL and dynamic hyperinflation have been shown to blunt the very important compensatory hyperventilation of heavy exercise (33, 40,41 ), and presumably the same should hold true for asthmatic subjects. Thus high-resistance airways might predispose many asthmatic subjects to a less robust ventilatory response and arterial hypoxemia during exercise. However, bronchodilation, which is known to occur during exercise in asthmatic subjects $(14,39,52)$, might help protect against excessive EFL in asthmatic subjects with airflow limitation at rest. The extent of exercise ventilatory constraint will consequently depend on the extent of baseline airflow limitation, the magnitude of exercise-induced bronchodilation, and the requirement for ventilation as dictated by the exercise workload.

The costs of publication of this article were defrayed in part by the payment of page charges. The article must therefore be hereby marked "advertisement" in accordance with 18 U.S.C. Section 1734 solely to indicate this fact. 
The aim of this study was to characterize the gas exchange and breathing mechanics responses to submaximal and highintensity exercise to exhaustion in habitually active asthmatic subjects. We also sought to determine the relations among airway inflammation, breathing mechanics, and gas exchange during the exercise and hypothesized that significant relations would exist among them.

\section{MATERIALS AND METHODS}

This study was approved by the Institutional Review Board and the Human Subjects Committee of the University of Wisconsin-Madison. Subjects were recruited by poster and newspaper advertisement, and by contact with university, community, and regional running, triathlon, and cycling clubs. Potential subjects were provided a detailed description of all study procedures and risks and agreed to participate after signing an informed consent form for human research.

\section{Subject Selection}

Habitually active men and women (aged 18-45 yr) with a known history of asthma or suspected asthma underwent several screening sessions to determine eligibility for participation (see Screening Studies). Potential subjects taking oral or inhaled steroids were excluded from study participation. A total of 94 individuals completed at least one screening study: 27 met the inclusion criteria for participation, and 21 of these subjects completed the entire protocol. The subjects consisted of five recreational triathletes, three recreational endurance runners, one cyclist, one collegiate ultimate Frisbee player, one collegiate football player, one competitive gymnast, one collegiate club hockey player, one equestrian athlete, and seven subjects who exercised for general health.

\section{Pulmonary Function Testing}

Lung volumes and forced expiratory flow rates were determined according to American Thoracic Society recommendations (3) with a commercially available system (Jaeger). Functional residual capacity (FRC) was measured in a body plethysmograph, and total lung capacity (TLC) was calculated as the sum of FRC and the inspiratory capacity (IC). Forced oscillation (IOS; model MS-IOS, Jaeger) was performed at a fixed breathing frequency and duty cycle (12 breaths/ min, duty cycle $=0.35$ ) and was used to determine total respiratory resistance (Rrs, $5 \mathrm{~Hz}$ ) and frequency dependence of resistance (Rrs, 5-25 Hz). Exhaled nitric oxide (eNO) was measured as described previously (50). A single-breath, breath-holding technique was used to determine diffusing capacity for carbon monoxide (45). A singlebreath $\mathrm{N}_{2}$-washout test was used to calculate closing volume and the slope of phase III during expiration as described previously (48).

\section{Sputum Induction and Processing and Inflammatory} Mediator Measurements

Subjects inhaled two actuations of albuterol 15 min before sputum induction. Nebulized 3\% hypertonic saline (Ultra-Neb, Devilbiss, Somerset, PA) was inhaled for $\sim 5$ min with a nose clip in place. Subjects then expectorated lung sputum into a sterile specimen container that was kept on ice throughout the procedure. This protocol was repeated until an acceptable volume of sputum was collected or the forced expiratory volume in $1.0 \mathrm{~s}\left(\mathrm{FEV}_{1.0}\right)$ had fallen by $>20 \%$, in which case albuterol was administered immediately. Mucus plugs were manually selected and processed as described previously (2). The same technician processed all sputum samples and completed all total and differential cell counts for each sputum study.

Competitive enzyme immunoassay kits (Cayman Chemical, Ann Arbor, MI) were used to measure histamine in the sputum supernatant and $9 \alpha, 11 \beta$-prostaglandin $\mathrm{F}_{2}\left(\mathrm{PGF}_{2}\right)$ in the urine.

\section{Methacholine Challenge}

Airway reactivity was determined using a five-breath dosimeter protocol with methacholine chloride (Provocholine, Methapharm, Coral Springs, FL) according to American Thoracic Society recommendations (4). After diluent inhalation, doubling doses of methacholine $(0.031-16 \mathrm{mg} / \mathrm{ml})$ diluted in saline were inhaled. After each dose, IOS and two forced vital capacity (FVC) maneuvers were performed (in that order), and the testing was concluded when $\mathrm{FEV}_{1.0}$ decreased by $\geq 20 \%$ from the postdiluent value or after the maximum dose of 16 $\mathrm{mg} / \mathrm{ml}$ was achieved.

\section{Arterial Blood Measurements}

Samples of arterial blood were drawn anaerobically over 10-20 s at rest and during exercise for measurement of arterial $\mathrm{PO}_{2}\left(\mathrm{~Pa}_{\mathrm{O}_{2}}\right)$, arterial $\mathrm{PCO}_{2}\left(\mathrm{~Pa}_{\mathrm{CO}_{2}}\right)$, and $\mathrm{pH}$ via a blood-gas analyzer (model ABL505, Radiometer, Copenhagen, Denmark), and oxyhemoglobin saturation $\left(\mathrm{Sa}_{\mathrm{O}_{2}}\right)$ was measured with a CO-oximeter (model OSM-3, Radiometer). Arterial blood lactate concentration was measured using an electrochemical analyzer (model 1500 Sport, Yellow Springs Instrument, Yellow Springs, OH).

\section{Exercise Study Apparatus}

The apparatus used for the exercise studies has been described previously (57). Room air (laboratory temperature $=24 \pm 1.2^{\circ} \mathrm{C}$, relative humidity $=47.6 \pm 12.4 \%$ ) was used as the inspirate for the first eight subjects enrolled in the study (Table 1). Compressed dry air from a gas cylinder $\left(0.21\right.$ inspired $\mathrm{O}_{2}$ fraction, laboratory temperature $=24 \pm 1.3^{\circ} \mathrm{C}$ ) was used as the inspirate for the remaining 13 subjects. For each individual subject, the same inspirate was breathed at all exercise workloads during the screening and arterial blood exercise studies.

\section{Breathing Mechanics Measurements During Exercise}

Before exercise, subjects performed several maximum volitional flow-volume loops (MFVLs) while standing on the treadmill and breathing on the same apparatus used during exercise. EFL was estimated as described previously (41), and end-expiratory lung volume (EELV) during exercise was determined by subtracting the exercise IC volume from TLC. Ventilatory capacity during exercise was estimated using the preexercise MFVL and the spontaneous exercise tidal flow-volume loops as described previously (34). Ventilatory capacity was thus calculated on the basis of the maximal expiratory flow rates achievable (as defined by the MFVL) at the actual operating lung and tidal volumes measured during the exercise. A nasopharyngeal 10-cm latex balloon-tipped catheter (Ackrad Laboratories, Cranford, NJ) connected by polyethylene tubing to a differential pressure transducer (Validyne) was used to measure esophageal pressure. Inspiratory pulmonary resistance $\left(\mathrm{RL}_{\mathrm{i}}\right)$ was calculated at peak inspiratory flow according to the technique of Mead and Whittenberger $(21,42)$.

\section{Medications}

Subjects were instructed to refrain from using short-acting $\beta$-agonists within $12 \mathrm{~h}$ and any long-acting $\beta$-agonists, antihistamines, leukotriene modifiers, and sodium cromoglycate within $48 \mathrm{~h}$ of each study. Table 2 includes a list of medications for each subject enrolled in the study. Additionally, subjects were instructed to refrain from ingesting any food, beverages, or other products containing caffeine for $\geq 8 \mathrm{~h}$ before all studies.

\section{Screening Studies}

Up to three separate screening studies were completed to determine eligibility for participation. Eligible subjects were required to demonstrate at least one of four inclusion criteria: 1 ) $\geq 12 \%$ increase in 
Table 1. Inclusion criteria results

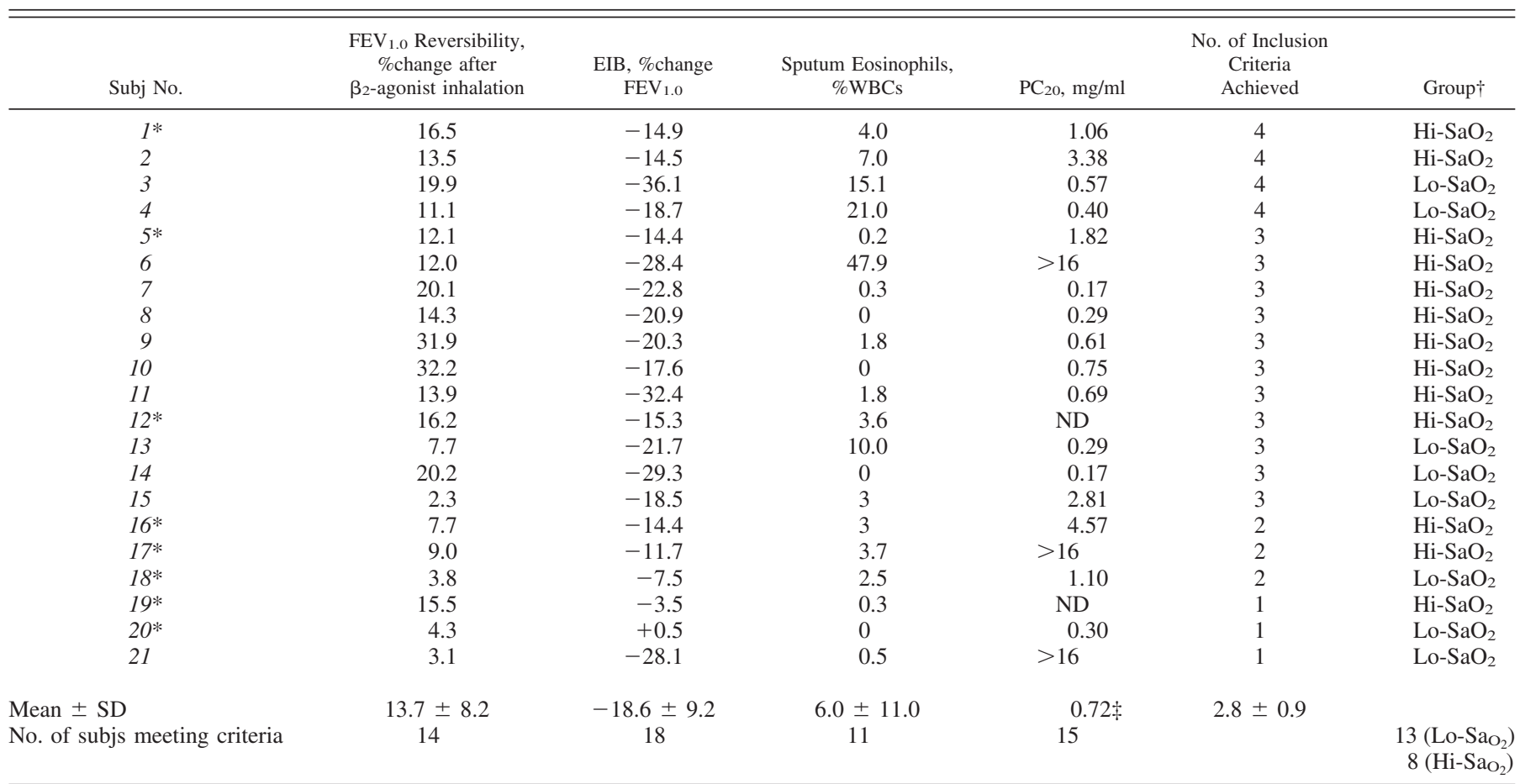

Subjects were ordered from 1-21 according to number of inclusion criteria met during the screening studies, beginning with subjects who met requirements of all 4 inclusion criteria. $\mathrm{FEV}_{1.0}$, forced expiratory volume in $1.0 \mathrm{~s} ; \mathrm{PC}_{20}$, methacholine concentration causing a $20 \%$ fall in $\mathrm{FEV}{ }_{1.0} ; \mathrm{Hi}_{-} \mathrm{Sa}_{\mathrm{O}_{2}}$, subjects with oxyhemoglobin saturation $>94 \%$ during prolonged bout; $\mathrm{Lo}_{-} \mathrm{Sa}_{\mathrm{O}_{2}}$, subjects with oxyhemoglobin saturation $\leq 94 \%$ during prolonged bout; ND, no data available; EIB, exercise-induced bronchospasm. *Subjects who breathed ambient air during exercise studies. †Allocation into Hi- or Lo-Sa $\mathrm{O}_{2}$ group was not among inclusion criteria and was determined retrospectively on completion of the exercise study. $\ddagger$ Geometric mean.

Table 2. Gender, $\dot{V} o_{2 \max }$, pulmonary function, medications, and atopy status

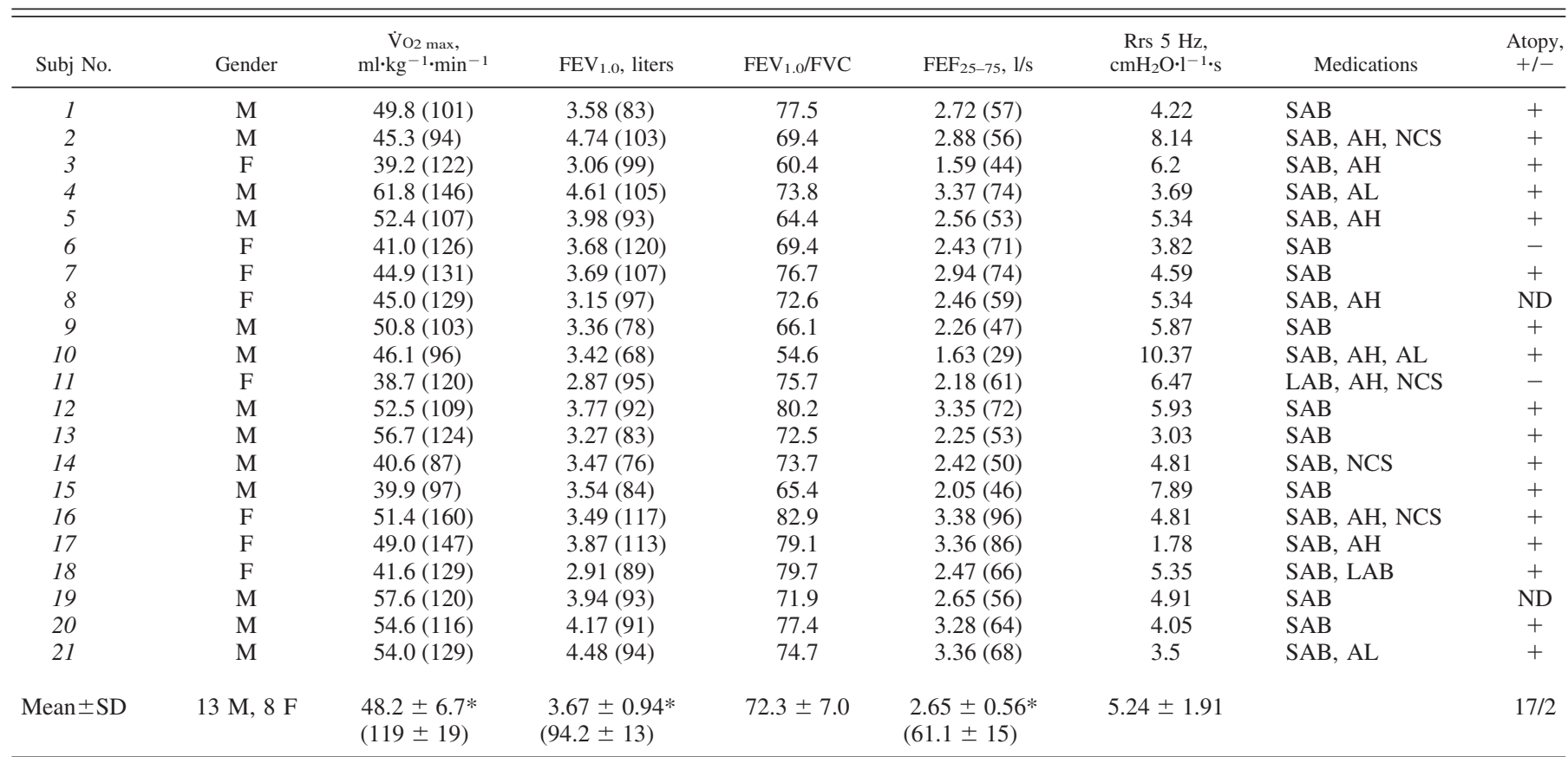

$\mathrm{VO}_{2}$ max , maximum $\mathrm{O}_{2}$ uptake; $\mathrm{FVC}$, forced vital capacity; $\mathrm{FEF}_{25-75}$, mean forced expiratory flow during middle $50 \%$ of $\mathrm{FVC}$; Rrs, total respiratory resistance at a frequency of $5 \mathrm{~Hz}$; SAB and LAB, short and long-acting $\beta$-agonist; $\mathrm{AH}$, antihistamine; AL, antileukotriene; NCS, nasal corticosteroid; ND, no data available. Prediction equations for $\mathrm{V}_{2}$ max for male $(\mathrm{M})$ and female $(\mathrm{F})$ subjects are from Refs. 11 and 16 respectively; prediction equations for $\mathrm{FEV}_{1.0}$ and $\mathrm{FEF}_{25-75}$ are from Ref. 36. *Percent predicted values (in parentheses) are significantly different from predicted values $(P<0.05)$. 
$\mathrm{FEV}_{1.0}$, from the baseline value, after inhalation of two actuations of albuterol, 2) demonstration of exercise-induced bronchospasm (EIB), defined as $\geq 10 \%$ decrease in $\mathrm{FEV}_{1.0}$ after an incremental exercise test to exhaustion, 3 ) $\geq 2 \%$ eosinophils (as percentage of white blood cells) in the cellular phase of the induced sputum, and 4) $\leq 4.0 \mathrm{mg} / \mathrm{ml}$ methacholine causing a $20 \%$ decrease in $\mathrm{FEV}_{1.0}\left(\mathrm{PC}_{20}\right)$.

Eligible subjects completed an exercise study designed to evaluate breathing mechanics and gas exchange during submaximal and highintensity exercise to exhaustion.

\section{Exercise Study Protocol}

Subjects voided their bladder immediately on arrival at the laboratory. Fluid ingestion was standardized and included a total of $800 \mathrm{ml}$ of water distributed in four servings (150-250 ml per serving) throughout the study. Preexercise lung function tests, including spirometry, IOS, FRC and TLC, and eNO, were completed. A 20-gauge arterial catheter was inserted percutaneously into a radial artery under local 1\% lidocaine anesthesia, and a nasopharyngeal temperature probe (Mallinckrodt Medical, St. Louis, MO) and balloon-tipped catheter were placed intranasally into the lower one-third of the esophagus. After the resting lung function tests and catheter placements, a baseline urine sample was collected. Immediately before the exercise, three MFVL and repeated IC maneuvers were performed while the subjects stood on the treadmill.

Subjects initially exercised at two submaximal workloads for $3 \mathrm{~min}$ each (sub-1 and sub-2), and blood samples were collected and IC maneuvers were performed during the final $30 \mathrm{~s}$ of each workload. After a brief ( $\sim 3-5 \mathrm{~min})$ rest, exercise was resumed and performed to exhaustion at a constant speed and grade (hereafter referred to as the prolonged exercise bout) that elicited a metabolic rate of $\sim 90 \%$ maximal $\dot{\mathrm{V}}_{2}\left(\dot{\mathrm{V}}_{2} \max\right.$, total exercise time $\left.=11.2 \pm 3.5 \mathrm{~min}\right)$. Arterial blood was collected every $2 \mathrm{~min}$, beginning at minute 1, and also at exhaustion. IC maneuvers were performed at similar time points. At $\sim 40$ min after completion of the prolonged exercise bout, another exercise test to exhaustion was performed; the details and results from this bout are presented elsewhere (27). A urine sample and induced sputum sample were collected 45 and $\sim 60 \mathrm{~min}$ after the final exercise test to exhaustion, respectively. The sputum results from the initial screening study were used as the baseline (i.e., preexercise) values with which to compare the postexercise sputum sample.

\section{Data Analyses}

Repeated-measures ANOVA containing one within-subject factor (measurement time) and one between-subjects factor (high- or low$\mathrm{Sa}_{\mathrm{O}_{2}}$ group; see RESULTS) was used to compare group mean values. If a significant main effect (group or time) or interaction (group $\times$ time) was observed, Tukey's post hoc test was used to determine where the significant differences existed. Relations between variables were determined using Pearson's correlation coefficients. Statistical significance was set at $P=0.05$. Unless otherwise stated, values are means $\pm \mathrm{SD}$.

\section{RESULTS}

\section{Inclusion Criteria Data}

Individual results from the screening studies are shown in Table 1. On average, subjects met 2.8 of the 4 inclusion criteria. Overall, EIB was the most prevalent of the four criteria (18 of 21 subjects), whereas $\geq 2 \%$ eosinophils in the sputum was the least prevalent (11 of 21 subjects). The $\mathrm{PC}_{20}$ criterion and percent change in $\mathrm{FEV}_{1.0}$ after albuterol inhalation were equally prevalent among the subjects. The severity of airway dysfunction and reactivity, as determined from one test, did not always correlate with the severity measured with a different test. Notably, in subjects 6, 17, and 21, EIB was significant but the $\mathrm{PC}_{20}$ was $>16.0 \mathrm{mg} / \mathrm{ml}$. On the basis of results from the screening studies, we have classified the asthma in the present group of subjects as mild to moderate (43a).

\section{Subject Characteristics}

Age, height, and body mass of the subjects were $25.5 \pm 6.0$ $\mathrm{yr}, 172.9 \pm 7.7 \mathrm{~cm}$, and $72.8 \pm 11.8 \mathrm{~kg}$, respectively. $\dot{\mathrm{V}}_{2} \max$, pulmonary function, medications, and atopy status for each subject are shown in Table $2 . \dot{V}_{2}$ max was on average $119 \%$ of the age-predicted value $(P<0.05$ vs. predicted). Overall, pulmonary function was slightly but significantly compromised relative to that of healthy age- and height-matched control subjects $\left[P<0.05\right.$ for $\mathrm{FEV}_{1.0}$ and forced expiratory flow at $25-75 \%$ of vital capacity $\left(\mathrm{FEF}_{25-75}\right)$ vs. predicted]. On average, subjects were mildly airflow limited according to the American Thoracic Society criteria for assessing an obstructive abnormality (3). There were exceptions, however: in subjects 3, 5, and 10, $\mathrm{FEV}_{1.0} / \mathrm{FVC}$ was $<65 \%$ and $\mathrm{FEF}_{25-75}$ was $29-53 \%$ of predicted. TLC (6.58 \pm 1.02 liters) and FRC (3.08 \pm 0.49 liters) were 102 and $100 \%$ of predicted normal (3), respectively, and diffusing capacity of the lung for carbon monoxide $\left(33.4 \pm 7.1 \mathrm{ml} \cdot \mathrm{min}^{-1} \cdot \mathrm{Torr}^{-1}\right)$ averaged $88 \%$ of the predicted value $[P<0.05$ vs. predicted (38)]. Mean phase III slope from the single-breath $\mathrm{N}_{2}$ washout averaged $1.19 \pm$ $0.50 \% \mathrm{~N}_{2} / 1$ (range $0.61-2.35 \% \mathrm{~N}_{2} / \mathrm{l}$ ), and slopes were $>2.0 \mathrm{SD}$ above the normal range $\left(1.97 \pm 0.26 \% \mathrm{~N}_{2} / 1\right)$ in 4 of 21 subjects (49). eNO was elevated (52.4 $\pm 35.6 \mathrm{ppb})$ compared with previous data in normal subjects, in which eNO measured using the same methodology was $\sim 25-35 \mathrm{ppb}(50,57)$.

\section{Exercise Responses}

Exercise-induced oxyhemoglobin desaturation. Subjects were divided into two groups on the basis of nadir $\mathrm{Sa}_{2}$ during the prolonged bout (15): those that maintained $>94 \% \mathrm{Sa}_{2}$ $\left[\right.$ mean $\left.\pm \mathrm{SD}, 95.6 \pm 1.0 \%\left(\mathrm{Hi}-\mathrm{Sa}_{\mathrm{O}_{2}}\right), n=13\right]$ and those in which $\mathrm{Sa}_{\mathrm{O}_{2}}$ decreased to $\leq 94 \%$ [mean $\pm \mathrm{SD}, 92.4 \pm 1.2 \%$, range 90.1-94.0\% (Lo-Sa $\left.\mathrm{O}_{2}\right), n=8$; Fig. 1A]. The Lo-Sa $\mathrm{O}_{2}$ group exhibited significant and sustained decreases in $\mathrm{Pa}_{2}$ beginning at sub-2 and at all times during the prolonged bout (Fig. $1 B$ ). In the $\mathrm{Hi}-\mathrm{Sa}_{\mathrm{O}_{2}}$ group, $\mathrm{Pa}_{\mathrm{O}_{2}}$ initially decreased 6.6 Torr at minute 1 of the prolonged bout, but thereafter it rose progressively so that it was slightly greater than the resting value by the end of exercise. Both groups exhibited a variable but progressive metabolic acidosis, and arterial blood lactate rose similarly in both groups during the exercise (Fig. 2).

In the Lo-Sa $\mathrm{O}_{2}$ group, the rapid drop in $\mathrm{Pa}_{\mathrm{O}_{2}}$ accounted for the majority of the initial fall in $\mathrm{Sa}_{\mathrm{O}_{2}}(69 \pm 14 \%$ of the total decrease in $\mathrm{Sa}_{2}$ at minute 1) during the prolonged bout. Thereafter, further decreases in $\mathrm{Sa}_{\mathrm{O}_{2}}$ were due solely to the effects of progressive decreases in $\mathrm{pH}$ and increases in body temperature on the position of the oxyhemoglobin dissociation curve. Thus, at the end of prolonged exercise, the decreased $\mathrm{Pa}_{\mathrm{O}_{2}}$ accounted for $17 \%$ and the combined effects of $\mathrm{pH}$ and temperature for the remaining $83 \%$ of the total decrease in $\mathrm{Sa}_{\mathrm{O}_{2}}$.

Metabolic rate and ventilation. There were no significant differences in $\dot{\mathrm{V}}_{2}$ between the groups during the exercise bouts (Table 3). During prolonged exercise, there was a progressive $\sim 34 \%$ rise in minute ventilation ( $\dot{\mathrm{V}}_{\mathrm{E}}$ ) from minute 1 to end exercise, and this increase was mediated solely by an 
A

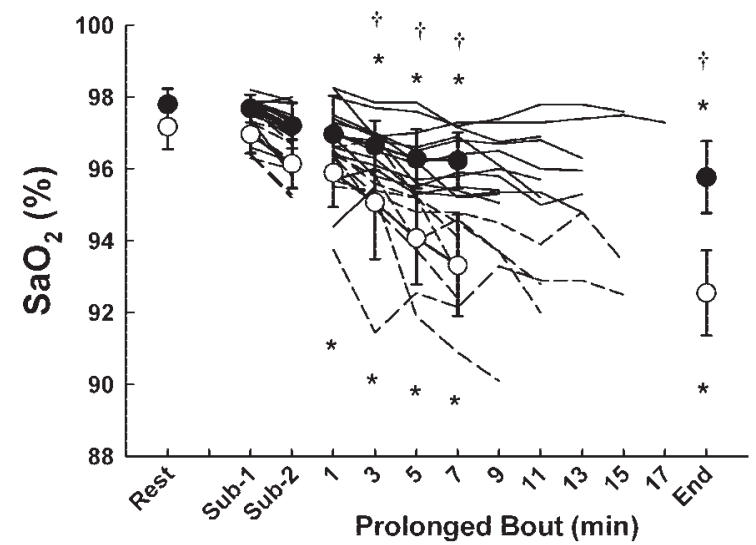

B

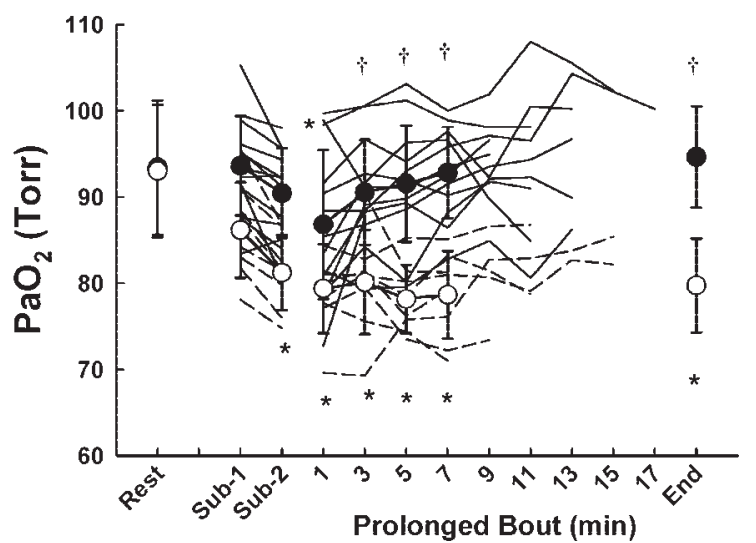

Fig. 1. Individual and group mean arterial blood oxygenation data for $>94 \%$ and $\leq 94 \%$ oxyhemoglobin saturation ( $\mathrm{Hi}$ - and $\mathrm{Lo}-\mathrm{Sa}_{2}, n=8$ and 13 , respectively) groups ( and $\bigcirc$, respectively) at rest, during submaximal exercise (sub-1 and sub-2), and during the prolonged exercise bout to exhaustion. $A$ : Sa $\mathrm{O}_{2} . B$ : arterial $\mathrm{PO}_{2}\left(\mathrm{PaO}_{2}\right)$. For individual data, solid lines represent $\mathrm{Hi}-\mathrm{SaO}_{2}$ subjects and dashed lines represent $\mathrm{Lo}-\mathrm{SaO}_{2}$ subjects. Values are means $\pm \mathrm{SD}$. ${ }^{*} \mathrm{Significantly}$ different from baseline $(P<0.05)$. †Significant difference between Hi- and $\mathrm{Lo}_{-} \mathrm{SaO}_{2}$ groups $(P<0.05)$.

increased breathing frequency in both groups. The dead spaceto-tidal volume ratio decreased from rest during exercise but rose significantly over the final half of prolonged exercise. The ventilatory equivalent for $\mathrm{CO}_{2}$ production $\left(\dot{\mathrm{VE}} / \dot{\mathrm{V}}_{\mathrm{CO}_{2}}\right)$ also rose over time during prolonged exercise and was significantly lower in the Lo- than in the Hi-Sa $\mathrm{O}_{2}$ group from minute 5 to the end of exercise.

Contributors to decreased $\mathrm{Pa}_{\mathrm{O}_{2}}$. There were clear differences between groups in the $\mathrm{A}-\mathrm{aDO}_{2}$ and $\mathrm{Pa}_{\mathrm{CO}_{2}}$ (Fig. 3): $\mathrm{A}-\mathrm{aDO}_{2}$ was wider and $\mathrm{Pa}_{\mathrm{CO}_{2}}$ was higher during exercise at all times in the $\mathrm{Lo}-\mathrm{Sa}_{\mathrm{O}}$ group. $\mathrm{A}-\mathrm{aDo}_{2}$ was on average $7.4 \pm 1.9$ Torr wider in the Lo- than in the $\mathrm{Hi}-\mathrm{Sa}_{\mathrm{O}_{2}}$ group during the prolonged bout $(P>0.05)$. In the $\mathrm{Hi}-\mathrm{Sa}_{\mathrm{O}_{2}}$ group, $\mathrm{Pa}_{\mathrm{CO}_{2}}$ decreased from rest to $34.0 \pm 2.7$ Torr by the end of the exercise $(P<0.0001)$. In contrast, in the $\mathrm{Lo}-\mathrm{Sa}_{\mathrm{O}_{2}}$ group, after a slight decrease from rest at minute 1 during the prolonged bout, $\mathrm{PaCO}_{2}$ rose progressively, increasing to $39.8 \pm 4.0$ Torr at exhaustion. $\dot{\mathrm{V}} \mathrm{E} / \dot{\mathrm{V}}_{\mathrm{CO}}$ was significantly correlated with $\mathrm{Pa}_{\mathrm{CO}_{2}}$ during prolonged exercise (Fig. 4), indicating that the primary determinant of $\mathrm{Pa}_{\mathrm{CO}_{2}}$ was the magnitude of the total ventilatory response. Additionally, the magnitudes of the $\mathrm{A}-\mathrm{aDo}_{2}$ and $\mathrm{Pa}_{\mathrm{CO}_{2}}$ were significantly correlated to $\mathrm{Pa}_{\mathrm{O}_{2}}$ (Fig. 5). Five subjects showed no hyperventilatory response to prolonged heavy-intensity exercise, i.e., $\mathrm{Pa}_{\mathrm{CO}_{2}}$ of $\sim 40$ Torr or greater at exercise termination.

$\mathrm{Pa}_{\mathrm{O}_{2}}$ can be viewed as a function of two variables: 1) the adequacy of the ventilatory response, as defined by the alveolar $\mathrm{PO}_{2}$, and 2) the efficiency of gas exchange, quantitated as $\mathrm{A}-\mathrm{aDO}_{2}$. The $\mathrm{A}-\mathrm{aDO}_{2}$ accounted for 62 and $75 \%$ of the decrease in $\mathrm{Pa}_{2}$ during submaximal exercise and early during the prolonged bout, respectively. The contribution of insufficient alveolar hyperventilation to the decreased $\mathrm{Pa}_{2}$ increased progressively from $25 \%$ during minute 1 of prolonged exercise to $46 \%$ at exercise termination.

Breathing mechanics. Pulmonary resistance was similar in the two groups before the exercise (Fig. 6), and although group means for $\mathrm{R}_{\mathrm{L}_{\mathrm{i}}}$ increased slightly from baseline during all three workloads, there were no major group mean timedependent changes during the prolonged bout. During the prolonged bout, in six subjects $\mathrm{R}_{\mathrm{L}_{\mathrm{i}}}$ was decreased at minute
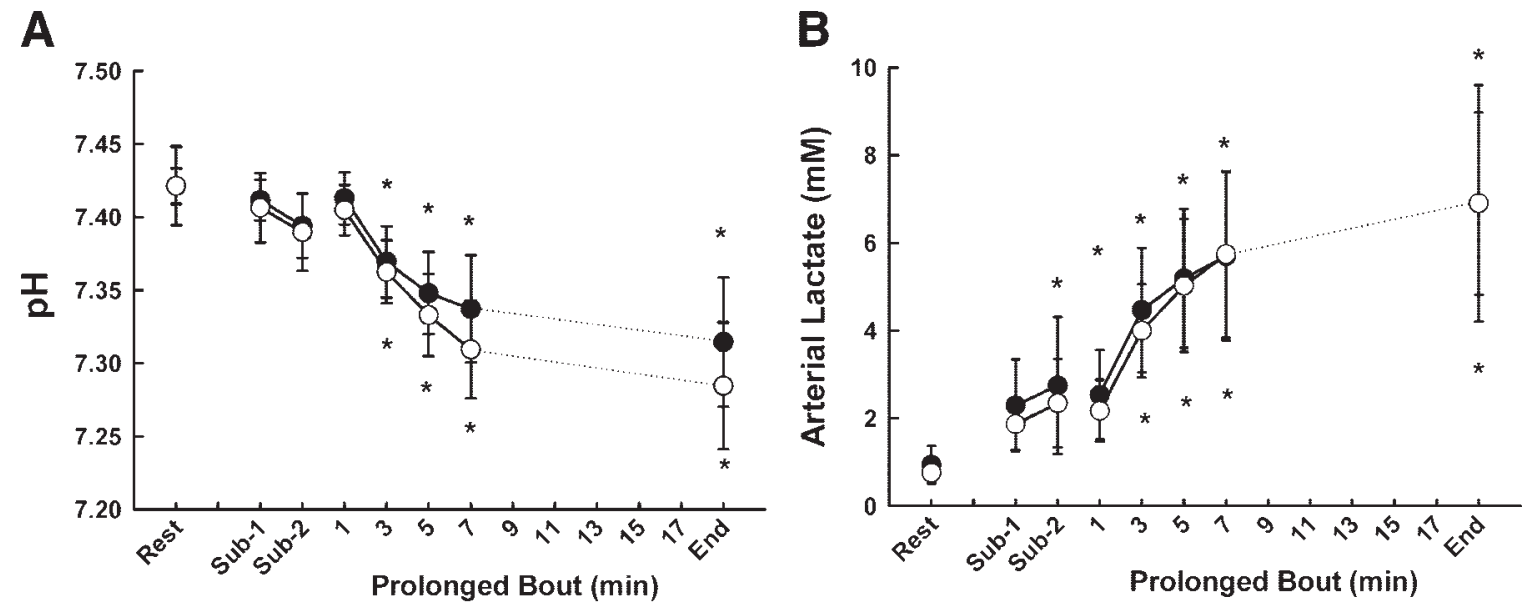

Fig. 2. Individual and group mean arterial $\mathrm{pH}(A)$ and blood lactate $(B)$ for Hi- and Lo-Sa $\mathrm{O}_{2}$ groups at rest, during submaximal exercise (sub-1 and sub-2), and during the prolonged exercise bout to exhaustion. Lines and symbols are described in Fig. 1 legend. Values are means \pm SD. *Significantly different from baseline $(P<0.05)$. Arterial blood bicarbonate decreased progressively throughout exercise from a mean resting value of $24.4 \pm 1.6$ meq to $16.7 \pm 2.0$ and $18.2 \pm 2.8$ meq at the end of exercise for the Hi- and $\mathrm{Lo}_{-} \mathrm{Sa}_{\mathrm{O}_{2}}$ groups, respectively (data not shown). 
Table 3. Resting and exercise metabolic rate and ventilation for the Hi- and $\mathrm{Lo}-\mathrm{Sa}_{\mathrm{O}_{2}}$ groups

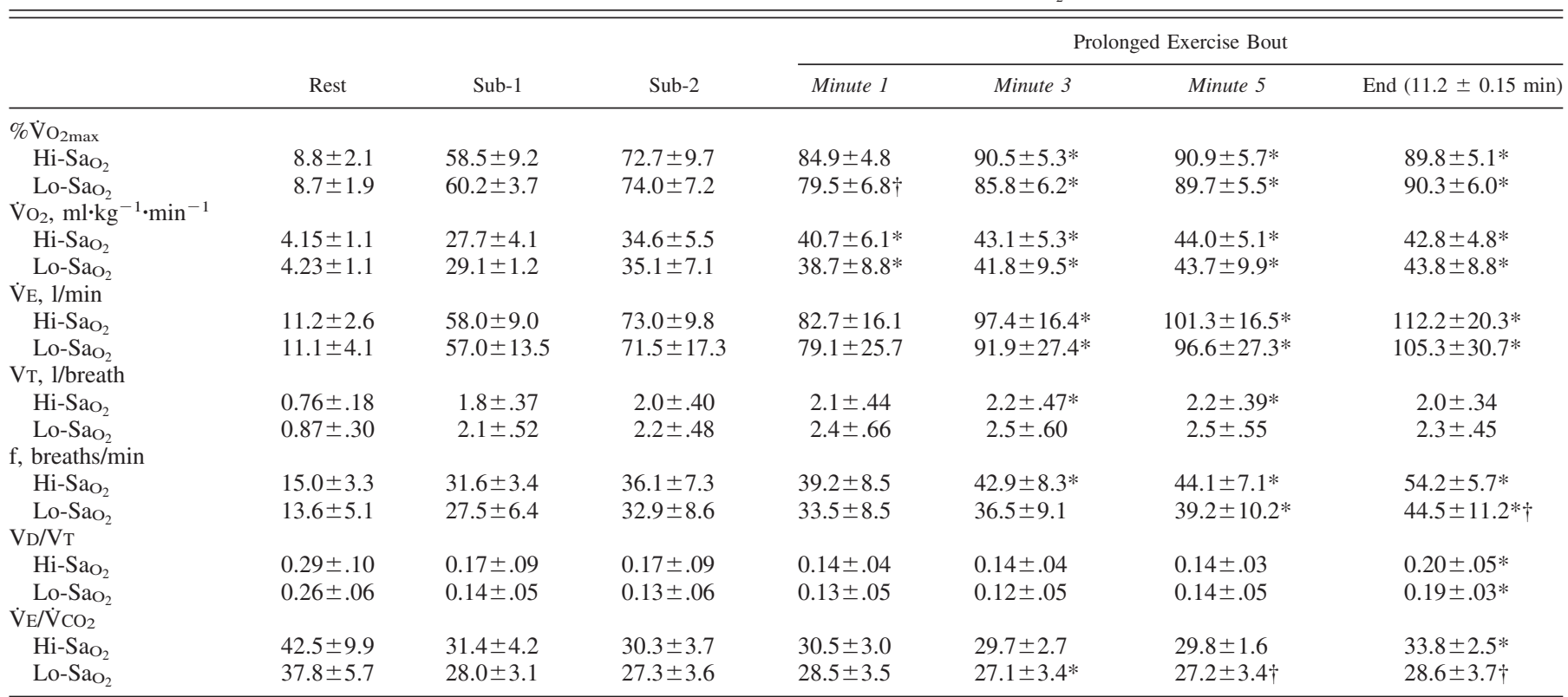

Values are means $\pm \mathrm{SD}$. $\mathrm{Sa}_{2}$, oxyhemoglobin saturation; sub-1 and sub-2, submaximal workloads; $\mathrm{VO}_{2}, \mathrm{O}_{2}$ uptake; VE, minute ventilation; VT, tidal volume; $\mathrm{f}$, breathing frequency; $\mathrm{VD} / \mathrm{VT}$, dead space-to-tidal volume ratio; $\dot{\mathrm{V}} / \mathrm{V}_{\mathrm{CO}}$; ventilatory equivalent for $\mathrm{CO}_{2}$ production. *Significantly different from minute 1 $(P<0.05)$. $†$ Significantly different from $\mathrm{Hi}_{-}-\mathrm{Sa}_{\mathrm{O}_{2}}(P<0.05)$.

1 compared with baseline $\left(-0.9 \pm 0.7 \mathrm{cmH}_{2} \mathrm{O} \cdot 1^{-1} \cdot \mathrm{s}\right)$, whereas in most of the subjects $(n=14), \mathrm{R}_{\mathrm{L}_{\mathrm{i}}}$ increased compared with baseline $\left(+1.4 \pm 1.2 \mathrm{cmH}_{2} \mathrm{O} \cdot 1^{-1} \cdot \mathrm{s}\right)$. After minute 1 of exercise, $\mathrm{R}_{\mathrm{L}_{\mathrm{i}}}$ remained unchanged or decreased in 19 subjects (average change from minute $1=-0.3 \pm 0.6$ $\mathrm{cmH}_{2} \mathrm{O} \cdot 1^{-1} \cdot \mathrm{s}$ ) and increased by $2.0 \mathrm{cmH}_{2} \mathrm{O} \cdot 1^{-1} \cdot \mathrm{s}$ at end exercise in 1 subject. There was a significant positive correlation between $\mathrm{R}_{\mathrm{i}}$ and $\mathrm{Pa}_{\mathrm{CO}}$ at the end of the prolonged bout $(r=0.45, P=0.05)$.

Several measurements of breathing mechanics at rest and during exercise are summarized in Table 4 . There were no significant differences between the $\mathrm{Hi}-$ and $\mathrm{Lo}-\mathrm{Sa}_{2}$ groups for any of the reported variables. Overall, ventilation was mechanically constrained; EFL was evident during at least one measurement time in all eight subjects in the $\mathrm{Lo}-\mathrm{Sa}_{\mathrm{O}}$ group and in 11 of the 13 subjects in the $\mathrm{Hi}-\mathrm{Sa}_{2}$ group during the exercise. Measured VE expressed as a percentage of ventilatory capacity reached 84 and $97 \%$ during the prolonged bout in the Hi- and $\mathrm{Lo}-\mathrm{Sa}_{\mathrm{O}_{2}}$ subjects, respectively. EELV was similar in the Hi- and $\mathrm{Lo}_{-} \mathrm{Sa}_{\mathrm{O}_{2}}$ groups throughout the exercise bouts, averaging $\sim 51 \%$ of TLC at rest, decreasing slightly during sub-1, and then increasing to resting levels during sub-2. During the prolonged bout, EELV increased progressively to $\sim 0.27$ liter greater than resting FRC at the final measurement in both groups. There were no significant correlations between EFL or $\dot{V}_{E}$ expressed as a percentage of ventilatory capacity and EELV/ TLC, $\dot{\mathrm{V}} / \mathrm{V}_{\mathrm{CO}} 2$, or $\mathrm{Pa}_{\mathrm{CO}_{2}}$ during the exercise bouts.
A

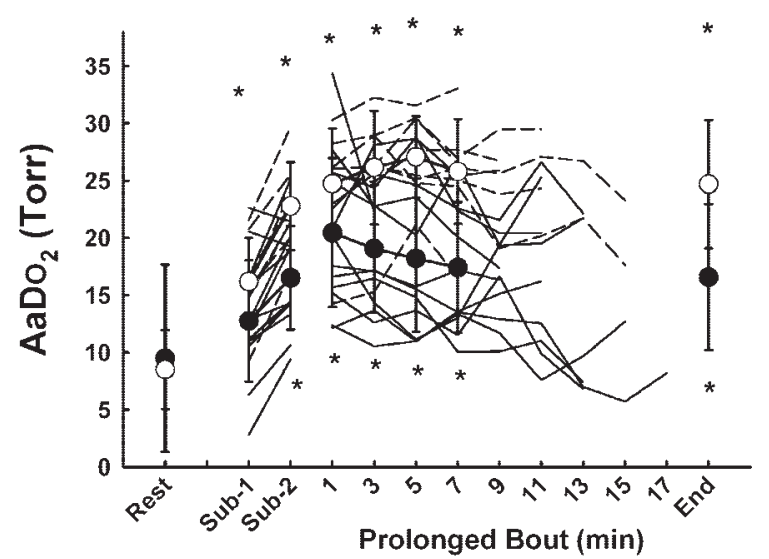

B

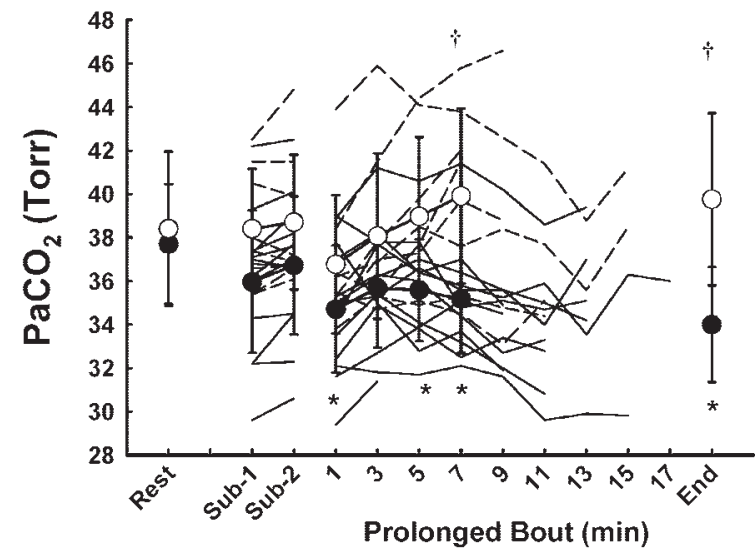

Fig. 3. Individual and group mean data for primary determinants of arterial $\mathrm{Po}_{2}$ : alveolar-to-arterial $\mathrm{Po}_{2}$ difference $\left(\mathrm{A}-\mathrm{aDO} \mathrm{O}_{2}\right)$, which represents gas exchange efficiency, and arterial $\mathrm{PCO}_{2}\left(\mathrm{PaCO}_{2}\right)$, which represents the magnitude of ventilatory response, in $\mathrm{Hi}-$ and $\mathrm{Lo}-\mathrm{Sa}_{2}$ groups at rest, during submaximal exercise (sub-1 and sub-2), and during the prolonged exercise bout to exhaustion. Lines and symbols are described in Fig. 1 legend. Values are means \pm SD. *Significantly different from baseline $(P<0.05)$. $†$ Significant difference between Hi- and Lo-Sa $\mathrm{O}_{2}$ groups $(P<0.05)$. 


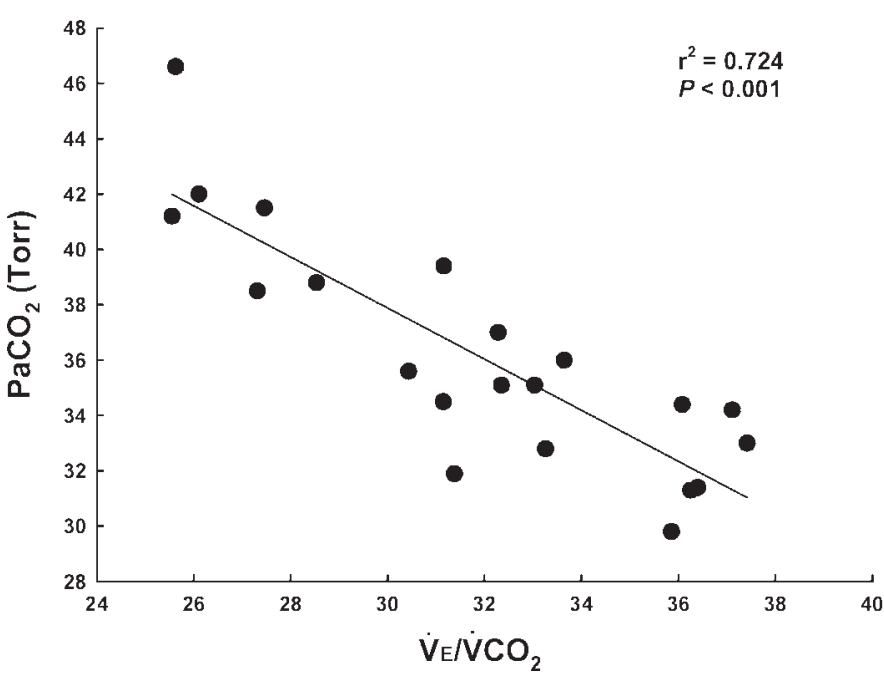

Fig. 4. Correlation between ventilatory equivalent for $\mathrm{CO}_{2}$ production ( $\dot{\mathrm{V}} \mathrm{E} /$ $\dot{\mathrm{V}} \mathrm{CO}_{2}$ ) and $\mathrm{PaCO}_{2}$ during prolonged exercise. Values were obtained at the end of the prolonged bout, just before exhaustion. $\mathrm{V} E / \mathrm{V} \mathrm{CO}_{2}$ was significantly correlated with $\mathrm{PaCO}_{2}$ during exercise $(P<0.05)$.

\section{Relations Between Baseline Pulmonary Function and Exercise Gas Exchange}

Baseline Rrs $5-25 \mathrm{~Hz}$ was higher in the $\mathrm{Lo}_{-} \mathrm{Sa}_{\mathrm{O}_{2}}$ group before exercise $\left(2.2 \pm 1.7\right.$ and. $0.8 \pm 1.3 \mathrm{cmH}_{2} \mathrm{O} \cdot 1^{-1} \cdot \mathrm{s}$ for Loand $\mathrm{Hi}-\mathrm{Sa}_{\mathrm{O}_{2}}$ subjects, respectively, $P=0.04$ ), but there were no other significant differences in baseline lung function between the groups. There were no significant correlations between baseline $\mathrm{FEV}_{1.0}, \mathrm{FEV}_{1.0} / \mathrm{FVC}, \mathrm{FEF}_{25-75}$, or Rrs at $5 \mathrm{~Hz}$ and the four measures of gas exchange (i.e., $\mathrm{Pa}_{\mathrm{O}_{2}}, \mathrm{~Pa}_{\mathrm{CO}_{2}}$, A- $\mathrm{aDo}_{2}$, and $\mathrm{Sa}_{2}$ ) during sub-1, sub-2, or the prolonged bout. However, baseline Rrs at $5-25 \mathrm{~Hz}$ was significantly correlated with $\mathrm{Pa}_{\mathrm{O}_{2}}(r=-0.53, P=0.01), \mathrm{Pa}_{\mathrm{CO}_{2}}(r=0.53, P=0.01)$, and $\mathrm{Sa}_{\mathrm{O}_{2}}(r=-0.47, P=0.03)$ at the end of the prolonged bout.

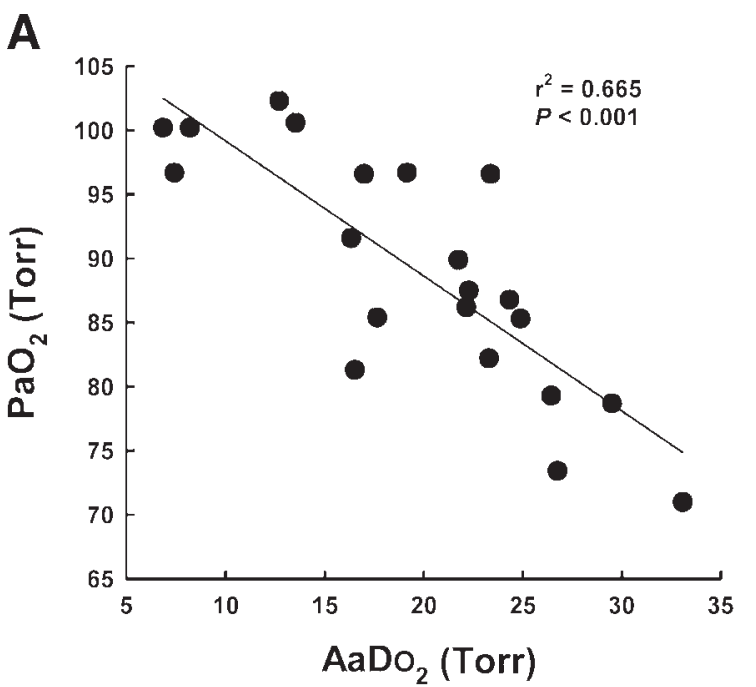

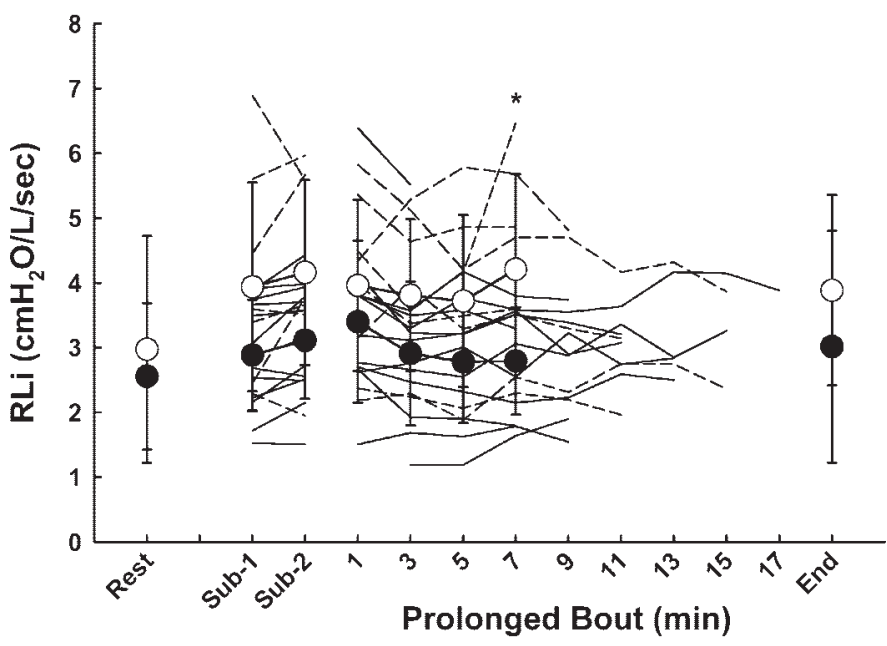

Fig. 6. Individual and group mean data for pulmonary resistance $\left(\mathrm{RL}_{\mathrm{i}}\right)$ in Hi- and Lo-Sa $\mathrm{O}_{2}$ groups at rest, during submaximal exercise (sub-1 and sub-2), and during the prolonged exercise bout to exhaustion. Lines and symbols are described in Fig. 1 legend. Values are means $\pm \mathrm{SD}$. *Significantly different from baseline $(P<0.05)$.

\section{Airway Inflammation}

Eosinophils at baseline amounted to $6 \%$ of the white blood cells in the sputum and did not change after exercise (Table 5). After exercise, urinary $9 \alpha, 11 \beta-\mathrm{PGF}_{2}$ was significantly increased by $117 \pm 207 \%$ from the baseline value when all subjects were combined and analyzed as one group. Sputum histamine after exercise was increased above baseline in the Lo-Sa $\mathrm{O}_{2}$ subjects $(37.8 \pm 27.1$ vs. $61.4 \pm 47.3 \mathrm{ng} / \mathrm{ml}, P=$ $0.04)$, but not in the $\mathrm{Hi}^{-\mathrm{Sa}_{2}}$ group (34.3 \pm 30.5 vs. $39.1 \pm$ $26.6 \mathrm{ng} / \mathrm{ml}, P=0.75)$. When all subjects were analyzed as one group, postexercise sputum histamine was significantly correlated with $\mathrm{Pa}_{\mathrm{O}_{2}}(r=-0.60, P=0.007)$ and the $\mathrm{A}-\mathrm{aDo}_{2}(r=$ $0.54, P=0.02$ ) measured at the end of the prolonged bout. Additionally, the change in histamine after exercise (i.e., the difference between postexercise and baseline) was significantly correlated with the changes in $\mathrm{Pa}_{\mathrm{O}_{2}}(r=-0.68, P=0.002)$

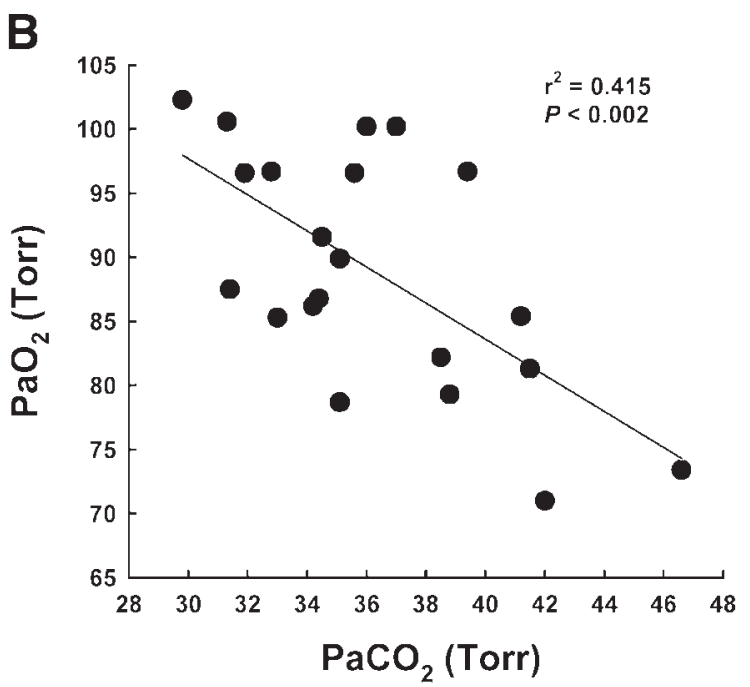

Fig. 5. Correlations between $\mathrm{PaO}_{2}$ and $\mathrm{A}-\mathrm{aDO}_{2}(A)$ and $\mathrm{Pa}_{\mathrm{CO}_{2}}(B)$ during the prolonged exercise bout. Values were obtained at the end of the prolonged bout, just before exhaustion. A-aDo ${ }_{2}$ and $\mathrm{Pa}_{C_{2}}$ were significantly related to exercise $\mathrm{Pa}_{2}(P<0.05)$. 
Table 4. Expiratory flow limitation, ventilatory capacity, and operating lung volumes at rest and during exercise in $\mathrm{Hi}$ - and $\mathrm{Lo}_{-} \mathrm{Sa}_{\mathrm{O}_{2}}$ groups

\begin{tabular}{|c|c|c|c|c|c|}
\hline & Rest & Sub-1 & Sub-2 & \multicolumn{2}{|c|}{ Prolonged Exercise Bout } \\
\hline \multicolumn{6}{|l|}{$\mathrm{EFL}, \% \mathrm{~V}_{\mathrm{T}}$} \\
\hline $\mathrm{Lo}-\mathrm{Sa}_{\mathrm{O}_{2}}$ & & $18.1 \pm 26.0$ & $35.7 \pm 29.6$ & $32.5 \pm 29.9$ & $54.3 \pm 30.4 \dagger+$ \\
\hline \multicolumn{6}{|l|}{ 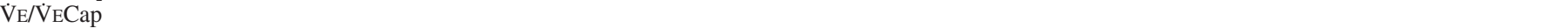 } \\
\hline $\mathrm{Hi}-\mathrm{SaO}_{2}$ & $0.12 \pm 0.05$ & $0.57 \pm 0.14^{*}$ & $0.70 \pm 0.18 *$ & $0.72 \pm 0.22^{*}$ & $0.84 \pm 0.20 * \dagger+$ \\
\hline $\mathrm{Lo}-\mathrm{Sa}_{2}$ & $0.18 \pm 0.11$ & $0.70 \pm 0.18^{*}$ & $0.79 \pm 0.18 *$ & $0.87 \pm 0.16^{*}$ & $0.97 \pm 0.24 * \dagger$ \\
\hline $\mathrm{Lo}-\mathrm{SaO}_{2}$ & $3.37 \pm 0.53$ & $3.22 \pm 0.64$ & $3.37 \pm 0.71$ & $3.23 \pm 0.88$ & $3.63 \pm 0.83 \dagger$ \\
\hline \multicolumn{6}{|l|}{ EELV/TLC } \\
\hline $\mathrm{Hi}-\mathrm{Sa}_{\mathrm{O}_{2}}$ & $0.52 \pm 0.08$ & $0.49 \pm 0.06$ & $0.51 \pm 0.06$ & $0.50 \pm 0.09$ & $0.55 \pm 0.06 \dagger$ \\
\hline $\mathrm{Lo}-\mathrm{SaO}_{2}$ & $0.51 \pm 0.04$ & $0.48 \pm 0.04$ & $0.50 \pm 0.06$ & $0.48 \pm 0.08$ & $0.54 \pm 0.06$ \\
\hline \multicolumn{6}{|l|}{ EILV, liters } \\
\hline $\mathrm{Hi}-\mathrm{Sa}_{\mathrm{O}_{2}}$ & $4.19 \pm 0.63$ & $5.17 \pm 0.70^{*}$ & $5.46 \pm 0.75^{*}$ & $5.33 \pm 0.69^{*}$ & $5.70 \pm 0.91 * \dagger$ \\
\hline Lo-Sa $\mathrm{O}_{2}$ & $4.35 \pm 0.79$ & $5.34 \pm 1.01 *$ & $5.61 \pm 1.01 *$ & $5.61 \pm 1.3^{*}$ & $5.93 \pm 1.16^{* \dagger}$ \\
\hline $\mathrm{Hi}-\mathrm{SaO}_{2}$ & $0.16 \pm 0.05$ & $0.37 \pm 0.06^{*}$ & $0.41 \pm 0.05^{*}$ & $0.42 \pm 0.07 * \dagger$ & $0.40 \pm 0.05^{*}$ \\
\hline $\mathrm{Lo}-\mathrm{SaO}_{2}$ & $0.17 \pm 0.05$ & $0.41 \pm 0.09^{*}$ & $0.43 \pm 0.08^{*}$ & $0.48 \pm 0.10^{*}$ & $0.47 \pm 0.07 *$ \\
\hline \multicolumn{6}{|l|}{ VT/IC } \\
\hline $\mathrm{Hi}-\mathrm{Sa}_{\mathrm{O}_{2}}$ & $0.25 \pm 0.09$ & $0.53 \pm 0.10^{*}$ & $0.62 \pm 0.09 * \dagger$ & $0.63 \pm 0.09 * \dagger$ & $0.68 \pm 0.09 * \dagger$ \\
\hline $\mathrm{Lo}-\mathrm{SaO}_{2}$ & $0.27 \pm 0.08$ & $0.60 \pm 0.10^{*}$ & $0.64 \pm 0.09 *$ & $0.68 \pm 0.10^{*}$ & $0.76 \pm 0.08 * \dagger$ \\
\hline
\end{tabular}

Values are means \pm SD. EFL, expiratory flow limitation; VE/V̈VCap, VE as a fraction of calculated ventilatory capacity; EELV, end-expiratory lung volume; TLC, total lung capacity; EILV, end-inspiratory lung volume; VC, vital capacity; IC, inspiratory capacity. *Significantly different from rest; †significantly different from sub-1; ‡significantly different from sub-2; §significantly different from minute $1(P<0.05)$.

and the $\mathrm{A}-\mathrm{aDo}_{2}(r=0.50, P=0.03)$ between rest and the end of the prolonged bout.

\section{Individual Subject Examples}

Figures 7 and 8 contrast the exercise results for two subjects with similar $\dot{\mathrm{V}}_{2}$ max and MFVLs but with different ventilatory responses and arterial blood gases during the exercise. Figure 7 shows a subject with a high $\mathrm{R}_{\mathrm{i}}$ at rest and a scooped

Table 5. Induced sputum cell counts and inflammatory mediators in sputum supernatant and urine

\begin{tabular}{|c|c|c|}
\hline & Baseline & Postexercise \\
\hline & \multicolumn{2}{|c|}{ Cell counts } \\
\hline No. of WBCs counted & $561 \pm 139$ & $516 \pm 163$ \\
\hline Total cells, WBCs/ml plug $\times 10^{6}$ & $2.2 \pm 2.6$ & $1.5 \pm 0.59$ \\
\hline Squamous epithelial, \%total cells & $29.0 \pm 15.0$ & $30.0 \pm 16.9$ \\
\hline Macrophages, \%WBCs & $85.7 \pm 12.5$ & $87.0 \pm 18.9$ \\
\hline Neutrophils, \%WBCs & $8.1 \pm 9.3$ & $3.9 \pm 1.6$ \\
\hline Lymphocytes, \%WBCs & $0.82 \pm 2.9$ & $0.14 \pm 0.26$ \\
\hline Eosinophils, \%WBCs & $6.0 \pm 11.0$ & $9.2 \pm 19.0$ \\
\hline Macrophages $\times 10^{6} / \mathrm{ml}$ plug & $1.8 \pm 2.0$ & $1.3 \pm 0.62$ \\
\hline Neutrophils $\times 10^{5} / \mathrm{ml}$ plug & $2.6 \pm 6.5$ & $0.65 \pm 0.88$ \\
\hline Lymphocytes $\times 10^{3} / \mathrm{ml}$ plug & $9.0 \pm 22.1$ & $2.3 \pm 5.3$ \\
\hline Eosinophils $\times 10^{5} / \mathrm{ml}$ plug & $1.1 \pm 2.7$ & $1.4 \pm 3.2$ \\
\hline
\end{tabular}

Sputum histamine, $\mathrm{ng} / \mathrm{ml}$ Urinary $9 \alpha, 11 \beta-\mathrm{PGF}_{2}, \mathrm{ng} / \mathrm{mmol}$ creatinine

Values are means $\pm \mathrm{SD}$. WBC, white blood cells; $\mathrm{PGF}_{2}$, prostaglandin $\mathrm{F}_{2}$ *Significantly different from baseline $(P<0.05)$. expiratory limb of the MFVL (forced expiratory flow at 50\% of vital capacity $=46 \%$ predicted). Consequently, EFL occurred at a very moderate increase in $\dot{V}_{\mathrm{E}}$, and substantial increases in EELV ensued. Pulmonary resistance decreased by $\sim 1.5$ $\mathrm{cmH}_{2} \mathrm{O} \cdot 1^{-1} \cdot \mathrm{s}$ during sub-1 and early during the prolonged bout but increased to the resting value during sub-2 and across time during the prolonged bout. Presumably at least in part because of the high resistive and elastic work of breathing, $\mathrm{Pa}_{\mathrm{CO}_{2}}$ rose progressively during the exercise, and concomitant decreases in $\mathrm{Pa}_{2}$ and $\mathrm{Sa}_{2}$ ensued. Finally, the unchanged expiratory limb of the immediate-postexercise MFVL shows the lack of a significant exercise-induced bronchodilatory response.

Similarly, Fig. 8 shows data from a subject with a high resting $\mathrm{R}_{\mathrm{i}}$, a scooped expiratory limb of the MFVL (forced expiratory flow at $50 \%$ of vital capacity $=69 \%$ predicted), and EFL during exercise. In contrast to the example in Fig. 7, however, EELV was maintained below FRC throughout the exercise and $\mathrm{R}_{\mathrm{i}}$ was decreased from rest at each exercise workload, remaining constant across time during the prolonged bout. Despite the ventilatory constraint, the exercise hyperventilatory response was adequate in this subject, and $\mathrm{Pa}_{\mathrm{O}_{2}}$ was maintained within the normal range.

\section{DISCUSSION}

\section{Summary of Findings}

Gas exchange and breathing mechanics were assessed in 21 habitually active asthmatic subjects during high-intensity, constant-work rate treadmill exercise to exhaustion. Significant decreases in $\mathrm{Sa}_{\mathrm{O}_{2}}$ during the exercise were noted in 8 of the 21 

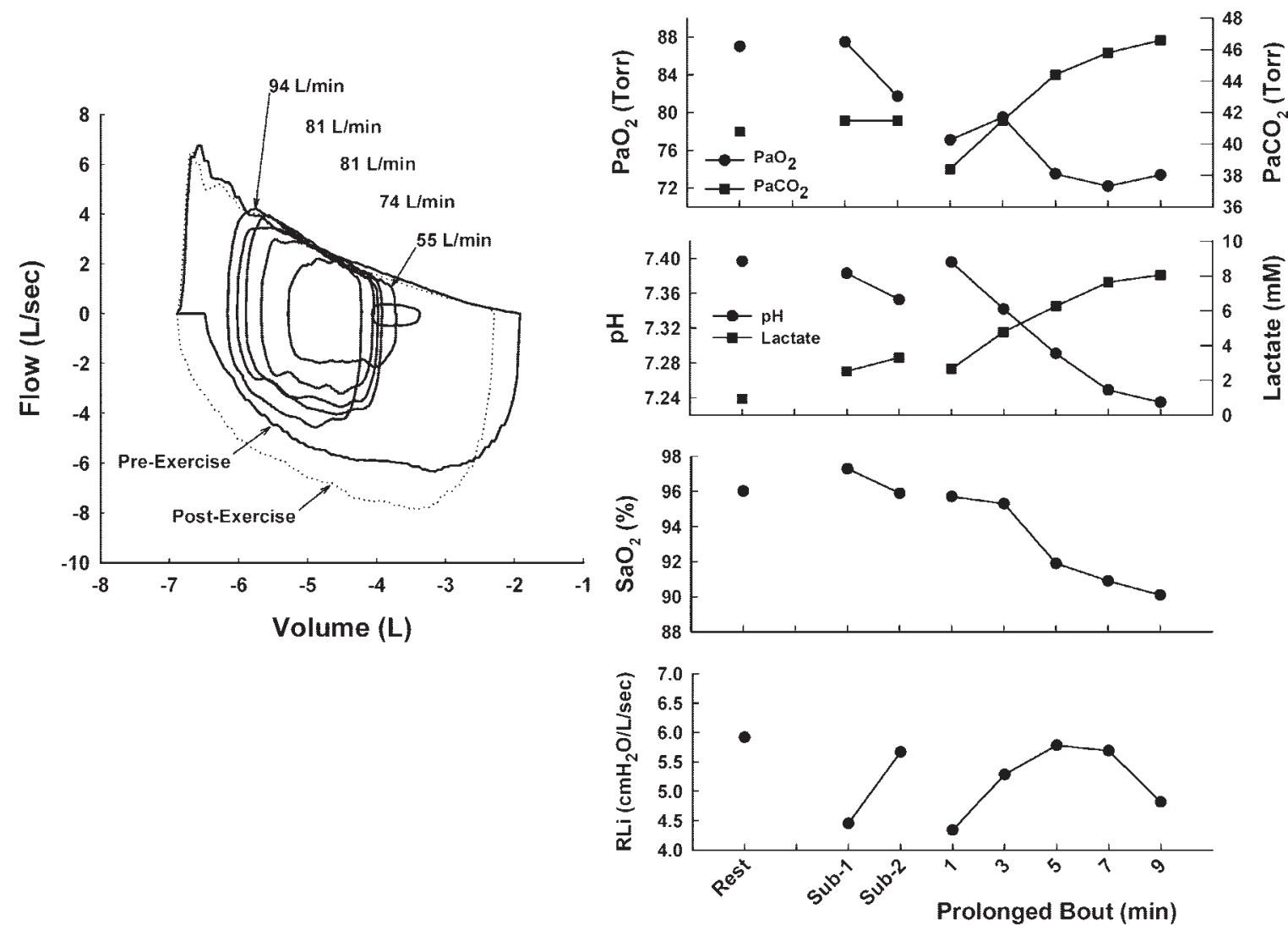

Fig. 7. Left: spontaneous exercise tidal flow-volume loops plotted within pre- and postexercise maximal flow-volume loops. Right: $\mathrm{Pa}_{\mathrm{O}_{2}}$ and $\mathrm{Pa}_{\mathrm{CO}_{2}}$, arterial $\mathrm{pH}$ and lactate, $\mathrm{Sa}_{\mathrm{O}_{2}}$, and $\mathrm{R}_{\mathrm{i}}$ at rest, during submaximal exercise (sub-1 and sub-2), and during prolonged exercise to exhaustion. Subject characteristics are as follows: male, $37 \mathrm{yr}$ old, maximal $\mathrm{O}_{2}$ uptake $=39.8 \mathrm{ml} \cdot \mathrm{kg}^{-1} \cdot \mathrm{min}^{-1}(97 \%$ predicted), forced vital capacity $(\mathrm{FVC})=5.25$ liters $(103 \%$ predicted), forced expiratory volume in $1.0 \mathrm{~s}\left(\mathrm{FEV}_{1.0}\right)=3.39$ liters $(80 \%$ predicted $), \mathrm{FEV}_{1.0} / \mathrm{FVC}=65 \%$, mean forced expiratory flow from $25-75 \%$ of vital capacity $=1.941 / \mathrm{s}$ (43.8\% predicted), respiratory system resistance at $5 \mathrm{~Hz}=8.98 \mathrm{cmH}_{2} \mathrm{O} \cdot 1^{-1} \cdot \mathrm{s}$, maximal voluntary ventilation $=100.4$ liters $(74.0 \%$ predicted).

subjects due in part to a decreased $\mathrm{Pa}_{\mathrm{O}_{2}}$, which in turn was caused by a widened $\mathrm{A}-\mathrm{aDO}_{2}$ and an insufficient ventilatory response. Ventilation was constrained during the exercise, as suggested by extensive EFL, a high fractional utilization of the maximum ventilatory capacity, pronounced dynamic hyperinflation, and a variable but high pulmonary resistance. These mechanical constraints likely contributed to the highly heterogeneous exercise ventilatory response, with several subjects exhibiting a rising $\mathrm{Pa}_{\mathrm{CO}_{2}}$ or frank $\mathrm{CO}_{2}$ retention $(>40$ Torr $\left.\mathrm{Pa}_{\mathrm{CO}_{2}}\right)$ during exercise. Sputum histamine and urinary $9 \alpha, 11 \beta-$ $\mathrm{PGF}_{2}$ were increased after exercise, providing evidence for an airway inflammatory response to the exercise stimulus. Furthermore, the postexercise sputum histamine levels were significantly correlated with several measures of gas exchange during exercise.

\section{Phenotypic Diversity Among Subjects}

We used four different tests of airway function to evaluate our subjects for airway pathology consistent with the diagnosis of asthma. Our subjects showed variable degrees of airway hyperresponsiveness, airflow limitation, and airway inflammation (Table 1). Thus the results from the inclusion criteria studies highlight the heterogeneity of bronchial asthma and the lack of association between different tests of airway function in asthmatic subjects.
Also, subjects 6, 17, and 21 had a $\mathrm{PC}_{20}>16 \mathrm{mg} / \mathrm{ml}$. This is important given the notion that airway hyperresponsiveness to direct-acting stimuli is necessary for the diagnosis of asthma. The alternative view is that asthma is more akin to a syndrome with multiple phenotypes and indicators of airway pathology (55). Asthma is a complex and heterogeneous condition, and in our view it is overly simplistic to ascribe the diagnosis of asthma on the basis of one outcome measure. Furthermore, we sought to study a group of subjects with a diverse range of airway characteristics consistent with the diagnosis of bronchial asthma.

\section{Exercise-Induced Arterial Hypoxemia}

In the present study, the decreased $\mathrm{Sa}_{\mathrm{O}_{2}}$ during prolonged heavy-intensity exercise was due almost equally to a decreased $\mathrm{Pa}_{\mathrm{O}_{2}}$ and a temperature- and $\mathrm{pH}$-induced shift in the oxyhemoglobin dissociation curve. Similar to previous findings in healthy young adults, the exercise $\mathrm{Pa}_{\mathrm{O}_{2}}$ was highly related to the efficiency of gas exchange, as measured with the $\mathrm{A}-\mathrm{aDO}_{2}$, and to the magnitude of the ventilatory response during the exercise, as revealed by the $\mathrm{Pa}_{\mathrm{CO}_{2}}$ (Fig. 5).

An important difference between the present study and previous studies on gas exchange during exercise in asthmatic subjects (see the introduction) is that our subjects were active and, therefore, capable of working at moderately high work 

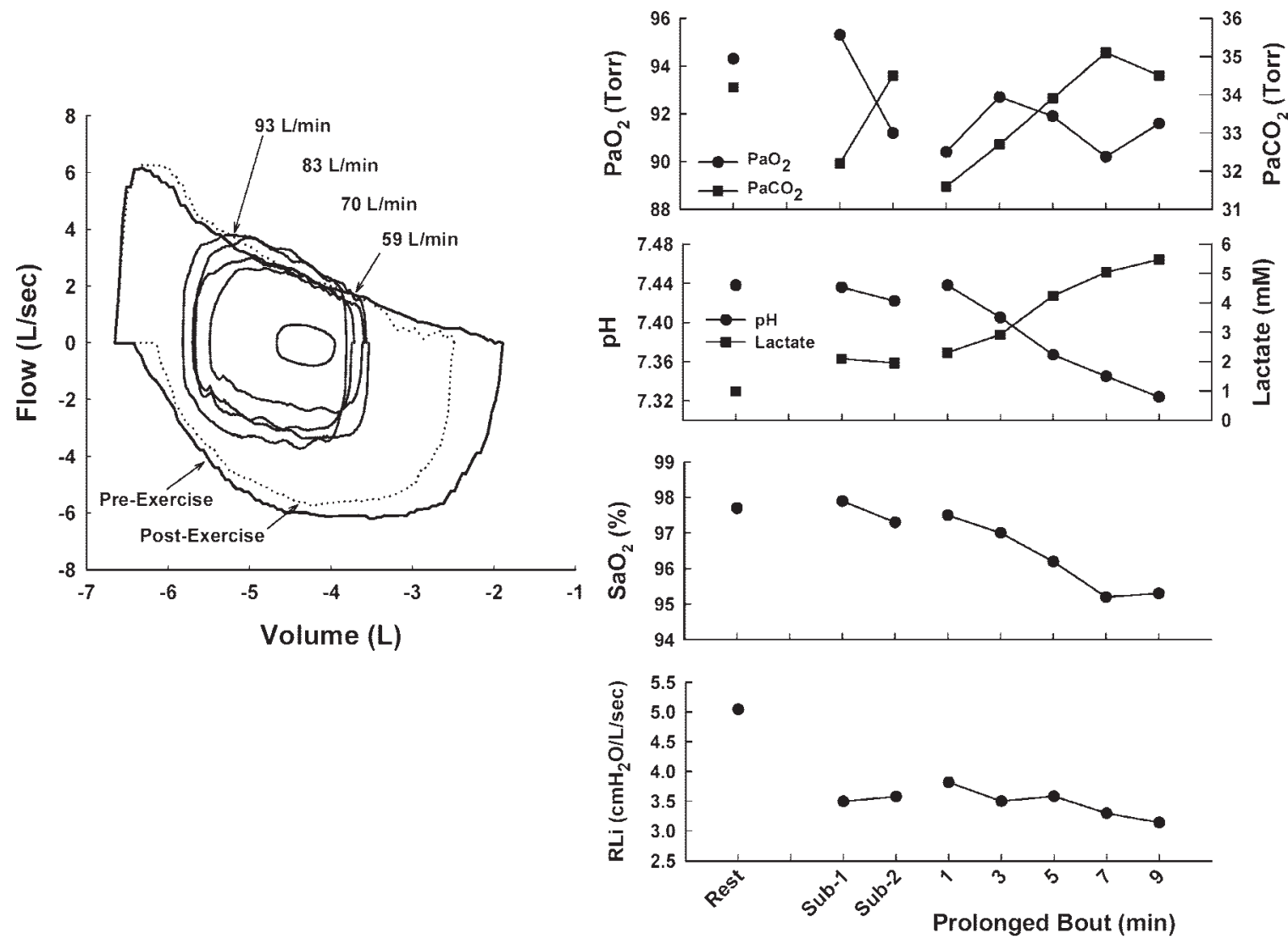

Fig. 8. Left: spontaneous exercise tidal flow-volume loops plotted within pre- and postexercise maximal flow-volume loops. Right: $\mathrm{PaO}_{2}$ and $\mathrm{PaCO}_{2}$, arterial $\mathrm{pH}$ and lactate, $\mathrm{SaO}_{2}$, and $\mathrm{RL}_{\mathrm{i}}$ at rest, during submaximal exercise (sub-1 and sub-2), and during prolonged exercise to exhaustion. Subject characteristics are as follows: 20-yr-old woman with maximal $\mathrm{O}_{2}$ uptake $=45 \mathrm{ml} \cdot \mathrm{kg}^{-1} \cdot \mathrm{min}^{-1}$ (131\% predicted), $\mathrm{FVC}=4.81$ liters $(120 \%$ predicted), $\mathrm{FEV}$ 1.0 $=3.69$ liters $(107 \%$ predicted), $\mathrm{FEV}_{1.0} / \mathrm{FVC}=77 \%$, mean forced expiratory flow from $25 \%$ to $75 \%$ of vital capacity $=2.94 \mathrm{l} / \mathrm{s}$ ( $74 \%$ predicted), respiratory system resistance at $5 \mathrm{~Hz}=4.59 \mathrm{cmH}_{2} \mathrm{O} \cdot 1^{-1} \cdot \mathrm{s}$, maximal voluntary ventilation $=113.0$ liters (97.7\% predicted). Lower $\mathrm{PaCO}_{2}$ in this subject than in the subject described in Fig. 7 legend was due to a higher $\mathrm{V} E / \mathrm{V} \mathrm{CO}_{2}$ during exercise (31 vs. 26 during the prolonged exercise bout).

rates and at a high percentage of their $\dot{\mathrm{V}}_{2}$ max for several minutes. Thus the exercise was at a sufficiently high metabolic requirement to stress the capacity of the cardiopulmonary system for gas exchange and $\mathrm{O}_{2}$ transport. Previous studies of asthmatic subjects exercising at lower exercise intensities have shown preservation of, or increased, $\mathrm{Pa}_{\mathrm{O}_{2}}$ during exercise (5, $12,19,20,24,35)$.

In the present group of subjects, the exercise-induced arterial hypoxemia (EIAH) occurred at lower exercise metabolic rates and in subjects with lower $\dot{\mathrm{V}}_{2}$ max than previously reported in healthy nonasthmatic individuals. In health, significant EIAH occurs only in a minority of subjects of moderate-to-high fitness who are able to achieve high metabolic rates for several minutes $(15,57)$; it is infrequent in men and women with a $\dot{\mathrm{V}}_{2}$ max of less than $\sim 60$ and $50 \mathrm{ml} \cdot \mathrm{kg}^{-1} \cdot \mathrm{min}^{-1}$, respectively $(30,57)$. In contrast, $50 \%$ of our asthmatic subjects ( 2 men and 2 women) in the $\mathrm{Lo}-\mathrm{Sa}_{\mathrm{O}_{2}}$ group had a $\dot{\mathrm{V}}_{2}$ max of $<42 \mathrm{ml} \cdot \mathrm{kg}^{-1} \cdot \mathrm{min}^{-1}$ (range 39.2-41.6) and were exercising at a mean metabolic rate of only $36.1 \pm 3.8 \mathrm{ml} \cdot \mathrm{kg}^{-1} \cdot \mathrm{min}^{-1}$ at the end of the prolonged bout. Furthermore, 10 of 21 subjects had a $\geq 10$-Torr decrease in $\mathrm{Pa}_{\mathrm{O}_{2}}$ during the prolonged exercise bout, with this initial drop persisting to the end of the bout in 7 of the 10 subjects. In contrast, Wasserman et al. (56) found no reduction in $\mathrm{Pa}_{\mathrm{O}_{2}}$ in 10 healthy but untrained men who performed constant-load cycle exercise to exhaustion at an exercise intensity similar to that used in our prolonged bout.

\section{Baseline Pulmonary Function and Arterial Blood Gas Status During Exercise}

Because of the potential for narrowed airways to alter the ventilation distribution and minimize the hyperventilation of heavy exercise, it is reasonable to hypothesize that the level of baseline airflow limitation might provide some prediction of arterial blood gas status during exercise in asthmatic subjects. However, for a given level of baseline airflow limitation in our subjects, exercise $\mathrm{Pa}_{\mathrm{O}_{2}}$ and $\mathrm{Pa}_{\mathrm{CO}}$ spanned a wide range of values. For example, for eight subjects, baseline $\mathrm{FEV}_{1.0} / \mathrm{FVC}$ was $\sim 0.65-0.70$ (and $\mathrm{FEF}_{25-75}$ was $55-60 \%$ predicted), but $\mathrm{Pa}_{\mathrm{O}_{2}}$ at end exercise was 71-97 Torr, $\mathrm{Pa}_{\mathrm{CO}_{2}}$ was 33-47 Torr, and $\mathrm{Sa}_{\mathrm{O}_{2}}$ was $90-96 \%$. Thus several subjects with compromised baseline lung function and significant EFL during exercise also hyperventilated normally and were able to maintain normal $\mathrm{Pa}_{2}$ during exercise.

The finding that resting lung function was not predictive of the adequacy of pulmonary gas exchange during high-intensity exercise in our subjects with asthma reflects the complexity of multiple factors operating during exercise. On the one hand, 
exercise causes progressive reductions in mixed venous $\mathrm{O}_{2}$ content, increases in cardiac output, and demands large increases in $\dot{V}_{\mathrm{A}}$, all of which should compromise arterial blood gas status in subjects with already impaired airway and gas exchange function. On the other hand, exercise promotes bronchodilation, which should improve the capacity for ventilation and also improve $\dot{V}_{\mathrm{A}} / \mathrm{Q}$ distribution. However, the magnitude of any exercise-induced bronchodilation is likely to be variable in asthmatic subjects, depending in part on the level of irreversible airflow limitation. For example, subjects 15, 18, 20 , and 21 showed some amount of baseline airflow limitation that was only minimally improved after $\beta$-agonist inhalation (Tables 1 and 2).

\section{Breathing Mechanics During Exercise}

Pulmonary resistance showed large variability among subjects during exercise: $\mathrm{RL}_{\mathrm{i}}$ was normal in several subjects $(\sim 2$ $\left.\mathrm{cmH}_{2} \mathrm{O} \cdot 1^{-1} \cdot \mathrm{s}\right)$ but increased in others $\left(>2-3 \mathrm{cmH}_{2} \mathrm{O} \cdot 1^{-1} \cdot \mathrm{s}\right)$ relative to values previously reported in healthy subjects $(8$, 21). The slight group mean increases in $R_{L_{i}}$ during exercise are largely explainable by the increased inspiratory flow rates (peak inspiratory flow $=0.7 \pm 0.2 \mathrm{l} / \mathrm{s}$ at rest vs. $4.7 \pm 1.0 \mathrm{l} / \mathrm{s}$ during prolonged exercise bout) and the nonlinearity of the pressure-flow relationship $(8,22)$. On the basis of previous studies that determined transpulmonary pressure at different inspiratory flow rates in otherwise resting humans $(22,42)$, we calculated that the increased inspiratory flow rates, per se, caused $\mathrm{a} \sim 1.0 \mathrm{cmH}_{2} \mathrm{O} \cdot 1^{-1} \cdot \mathrm{s}$ increase in mean $\mathrm{R}_{\mathrm{i}}$ at minute 1 of the prolonged exercise bout. This accounts for all the observed increase in $\mathrm{R}_{\mathrm{i}}$ in 10 of the 14 subjects who demonstrated an increase relative to rest at this time. The increased $\mathrm{RL}_{\mathrm{i}}$ in the remaining four subjects $\left(+2.1 \pm 1.2 \mathrm{cmH}_{2} \mathrm{O} \cdot 1^{-1} \cdot \mathrm{s}\right.$ vs. baseline after correction for increased flow rates) was beyond that attributable to increased inspiratory flow rate, per se, indicating a decrease in airway caliber during exercise in these subjects.

After minute 1 of prolonged exercise, all but one subject exhibited an unchanged or decreased $\mathrm{R}_{\mathrm{i}}$ across time, despite the increasing inspiratory flow rates, strongly suggesting an exercise-induced bronchodilation. These findings are consistent with the bronchodilatory effect of exercise previously reported in most asthmatic subjects $(14,39,51,53)$. In one subject, a marked increase in $\mathrm{R}_{\mathrm{i}}$ was noted during the prolonged bout, a finding similar to that reported by Beck et al. (7), in which a subject experienced marked increases in airway resistance during exercise. Thus the airways in a small minority of asthmatic subjects are especially hyperresponsive to the exercise stimulus, despite the strong bronchodilatory influences during exercise.

Our subjects were expiratory flow limited and utilized a large fraction of their ventilatory capacity during exercise. Significant dynamic hyperinflation ensued, and mean EELV increased to well above resting FRC during the prolonged bout. These findings are in general agreement with those from previous studies in asthmatic subjects $(34,52,53)$. Moreover, in the present group of subjects, EFL occurred during sub-1 in seven subjects, at a $\dot{V}_{E}$ of only $\sim 62$ 1/min, and during sub- 2 in 10 subjects, at a $\dot{V}_{E}$ of $\sim 78$ 1/min. Conversely, in nonasthmatic young adult men and women, EFL does not normally occur until VE approaches or exceeds $\sim 120$ and $\sim 100$ 1/min, respec- tively $(33,40,41)$. Thus asthmatic subjects experience EFL at lower exercise work rates and to a greater degree than their nonasthmatic counterparts.

\section{Heterogeneous Hyperventilatory Response During Exercise}

In the present study, $\mathrm{Pa}_{\mathrm{CO}_{2}}$ spanned a wide range of values at all exercise workloads. During submaximal exercise, the mean values for $\mathrm{Pa}_{\mathrm{CO}}$, were consistent with results from the literature that reported arterial blood gases during treadmill exercise in asthmatic $(5,12)$ and nonasthmatic $(29,57)$ subjects. In contrast, during high-intensity exercise (i.e., prolonged bout), several subjects displayed a normal exercise hyperventilation $\left(<35\right.$ Torr $\left.\mathrm{Pa}_{\mathrm{CO}_{2}}\right)$, whereas others showed a high or progressively rising $\mathrm{Pa}_{\mathrm{CO}_{2}}$ across time. Furthermore, four subjects had frank $\mathrm{CO}_{2}$ retention (41.2-46.6 Torr $\mathrm{Pa}_{\mathrm{CO}_{2}}$ ) at end exercise. The high prevalence of an insufficient hyperventilatory response in our subjects contrasts with previous studies in asthmatic subjects who showed a normal or even greater hyperventilation during exercise than healthy control subjects $(5,12,19,24,28,35)$. The moderate exercise intensities used in these studies, however, required only modest increases in $\dot{V}_{\text {A, }}$ which did not stress the capacity of the pulmonary system to generate airflow. However, one of five subjects in a previous study did retain $\mathrm{CO}_{2}(\sim 45$ Torr $)$ during moderate-intensity treadmill exercise (5).

What are the causes of the heterogeneous ventilatory response during exercise in the present group of asthmatic subjects? First, it is clear that the failure to adequately reduce $\mathrm{Pa}_{\mathrm{CO}_{2}}$ was due to an inadequate increase in $\dot{\mathrm{V}}$, rather than an excessive dead space-to-tidal volume ratio (Fig. 4). Ventilation during high-intensity exercise is determined by the net effect of two competing influences: 1 ) the magnitude of and sensitivity to multiple feedforward and chemoreceptor- and locomotorlinked feedback inputs to the brain stem acting to stimulate ventilation out of proportion to $\mathrm{CO}_{2}$ production (45), and 2) the constraints on ventilation imposed by the mechanical characteristics of the extra- and intrathoracic airways and chest wall, in combination with the capacity for pressure development by the respiratory muscles. In this regard, many of the asthmatic subjects in this study had a high airway resistance with a compromised capacity for expiratory airflow (i.e., high flowresistive work of breathing) and a high elastic work of breathing and shortened diaphragm as a consequence of dynamic hyperinflation during the exercise. EFL is also associated with an increased EELV and attenuates the exercise hyperventilation during high-intensity exercise in healthy, young highly fit men $(33,41)$ and women $(40)$, in physically active older adults (31), and in subjects with chronic airflow limitation (44). Importantly, however, the extent of mechanical constraint and dynamic hyperinflation in our subjects was markedly greater than that seen in even highly fit athletes exercising at higher metabolic rates with far greater ventilatory requirements.

We also emphasize the finding that several subjects with substantial EFL maintained a reduced EELV and also showed the typical normal hyperventilation of heavy sustained exercise (Fig. 8). The factors accounting for the heterogeneous ventilatory response in the face of similar degrees of constraint in this group of asthmatic subjects are unknown. Interindividual differences in sensitivity to the multiple chemoreceptor- and locomotor-linked stimuli to breathe may explain some of the 
difference (26). In health, there is also variation in the physiological response to EFL, in terms of its effects on operating lung volumes and on the ventilatory response (33). We can only conclude that EFL and a high VE expressed as a percentage of ventilatory capacity were present in all subjects who lacked a sufficient hyperventilation during the exercise; however, EFL, per se, did not always result in a blunted ventilatory response during exercise.

\section{Airway Inflammation}

There is good reason to postulate a relation between airway inflammation and gas exchange during exercise (see the introduction). Exercise caused an increase in urinary $9 \alpha, 11 \beta-\mathrm{PGF}_{2}$ when all subjects were analyzed as one group and an increase in sputum histamine in the $\mathrm{Lo}^{-\mathrm{Sa}_{\mathrm{O}_{2}}}$ group only, providing evidence for mast cell degranulation during or shortly after exercise in asthmatic subjects. Other investigators also showed an increase in urinary $9 \alpha, 11 \beta-\mathrm{PGF}_{2}$ after exercise in asthmatic subjects $(43,46)$. The osmotic hypothesis of EIB stipulates that inflammatory mediators be released into the airway wall during or shortly after exercise (6); however, previous studies are inconsistent regarding the airway inflammatory response to exercise in asthmatic subjects $(10,13,23,31,36,43,46)$. Some of the discrepancy is probably due to the difficulty in accurately detecting changes in inflammatory mediators in the airway lumen or mucosal layer, differences in metabolism of the mediators and the time interval between exercise and collection of sputum or bronchoalveolar lavage, and differences in exercise work rate between the separate studies.

Does airway inflammatory mediator release in response to exercise in asthmatic subjects affect gas exchange during the provocative exercise bout? On the one hand, we found significant correlations between postexercise sputum histamine and $\mathrm{A}-\mathrm{aDO}_{2}$ and $\mathrm{PaO}_{2}$ during exercise and also between the exercise-induced change in histamine and the differences in $\mathrm{PaO}_{2}$ and $\mathrm{A}-\mathrm{aDo}_{2}$ between end exercise and rest. Thus exercise $\mathrm{Pa}_{\mathrm{O}}$ was lower and $\mathrm{A}-\mathrm{aDO}_{2}$ was wider in subjects with increased sputum histamine after exercise. If released during exercise, the effects of these mediators on the bronchial vasculature and smooth muscle may have caused a worsened ventilation distribution and perpetuated the development of arterial hypoxemia, even in the absence of reductions in large airway caliber during exercise. Indeed, inhalation of the inflammatory mediators histamine, leukotriene $\mathrm{D}_{4}$, and platelet-activating factor causes an increase in resting $\mathrm{A}-\mathrm{aDo}_{2}$ and a decrease in $\mathrm{Pa}_{2}$ in asthmatic subjects $(1,17,18)$.

On the other hand, the lack of a time-dependent increase in A- $\mathrm{aDO}_{2}$ or decrease in $\mathrm{Pa}_{\mathrm{O}_{2}}$ beyond minute 1 of exercise (Figs. 1 and 3 ) suggests that the inflammatory mediator release did not occur during but only after the exercise [the conventional but untested hypothesis (6)] or that any mediator release during exercise does not negatively impact pulmonary gas exchange. One of the principal effects of inflammatory mediator release is bronchial smooth muscle contraction, but the bronchoprotective effect of exercise in asthmatic subjects (51) might prevent this contraction. Other compensatory mechanisms that would help prevent deterioration in gas exchange in the face of inflammatory mediator release include regional hypoxic pulmonary vasoconstriction, collateral ventilation, and the increase in overall $\dot{\mathrm{V}}_{\mathrm{A}} / \mathrm{Q}$ during exercise. Constant-load, high- intensity exercise in nonasthmatic subjects also does not result in any time-dependent decreases in $\mathrm{Pa}_{\mathrm{O}_{2}}$ or increases in $\mathrm{A}-\mathrm{aDo}_{2}$ beyond minute 1 of exercise $(29,57)$, and acute administration of a cocktail of anti-inflammatory agents before exercise in trained young nonasthmatic subjects had no effect on gas exchange during exercise (58). Future studies that acutely block or chronically treat the airway inflammation of asthma are a necessary next step to rigorously determine the effects of airway inflammation on exercise gas exchange.

\section{Conclusions}

Habitually active, mildly to moderately asthmatic subjects appear to develop exercise-induced arterial hypoxemia at lower metabolic rates than their nonasthmatic counterparts. This is related in large part to an insufficient exercise ventilatory response, likely as a consequence of substantial mechanical constraints for ventilation at only moderate levels of $\dot{\mathrm{V}}$. Additionally, we found evidence supporting a role for airway inflammatory mediator release in the widened $\mathrm{A}-\mathrm{aDO}_{2}$ and decreased $\mathrm{PaO}_{2}$ during exercise in asthmatic subjects.

\section{ACKNOWLEDGMENTS}

We are grateful to our subjects for their time and enthusiastic participation. We thank Dr. Nizar Jarjour and his research staff (University of Wisconsin Hospital and Clinics) for teaching us procedures for methacholine challenge and induced sputum tests and also for conducting all the skin testing, Alana Brennan for processing and analyzing the induced sputum, Dr. Andrew Lovering for invaluable help with the mediator assays, and Drs. Jonathon Spahr and Marcus Santana (University of Wisconsin Hospital and Clinics) for placing the arterial catheters.

\section{GRANTS}

This research was supported by National Heart, Lung, and Blood Institute Grants RO1-HL-015469 and T32-HL-07654 (H. C. Haverkamp and J. D. Miller) and the Veterans Affairs/Department of Defense.

\section{REFERENCES}

1. Acuna AA, Gabrijelcic J, Uribe EM, Rabinovich R, Roca J, Barbera JA, Chung KF, and Rodriguez-Roisin R. Fluticasone propionate attenuates platelet-activating factor-induced gas exchange defects in mild asthma. Eur Respir J 19: 872-878, 2002.

2. Alexis NE, Soukup J, Nierkens S, and Becker S. Association between airway hyperreactivity and bronchial macrophage dysfunction in individuals with mild asthma. Am J Physiol Lung Cell Mol Physiol 280: L369-L375, 2001.

3. American Thoracic Society. Lung function testing: selection of reference values and interpretative strategies. Am Rev Respir Dis 144: 1202-1218, 1991

4. American Thoracic Society. Guidelines for methacholine and exercise challenge testing-1999. Am J Respir Crit Care Med 161: 309-329, 2000.

5. Anderson SD, Silverman M, and Walker SR. Metabolic and ventilatory changes in asthmatic patients during and after exercise. Thorax 27: $718-725,1972$.

6. Anderson SD and Daviskas E. The mechanism of exercise-induced asthma is. . . J Allergy Clin Immunol 106: 453-459, 2000.

7. Beck KC, Offord KP, and Scanlon PD. Bronchoconstriction occurring during exercise in asthmatic subjects. Am J Respir Crit Care Med 149: 352-357, 1994.

8. Beck KC, Hyatt RE, Mpougas P, and Scanlon PD. Evaluation of pulmonary resistance and maximal expiratory flow measurements during exercise in humans. J Appl Physiol 86: 1388-1395, 1999.

9. Bousquet J, Jeffery PK, Busse WW, Johnson W, and Vignola AM. Asthma. From bronchoconstriction to airways inflammation and remodeling. Am J Respir Crit Care Med 161: 1720-1745, 2000.

10. Broide DH, Eisman S, Ramsdell JW, Ferguson P, Schwartz LB, and Wasserman SI. Airway levels of mast cell-derived mediators in exerciseinduced asthma. Am Rev Respir Dis 141: 563-568, 1990. 
11. Bruce RA, Kusumi F, and Hosmer D. Maximal oxygen intake and nomographic assessment of functional aerobic impairment in cardiovascular disease. Am Heart J 85: 546-562, 1973.

12. Bye PT, Anderson SD, Daviskas E, Marty JJ, and Sampson D. Plasma cyclic AMP levels in response to exercise and terbutaline sulphate aerosol in normal and asthmatic subjects. Eur J Respir Dis 61: 287-297, 1980.

13. Crimi E, Balbo A, Milanese M, Miadonna A, Rossi GA, and Brusasco V. Airway inflammation and occurrence of delayed bronchoconstriction in exercise-induced asthma. Am Rev Respir Dis 146: 507-512, 1992.

14. Crimi E, Pellegrino R, Smeraldi A, and Brusasco V. Exercise-induced bronchodilation in natural and induced asthma: effects on ventilatory response and performance. J Appl Physiol 92: 2353-2360, 2002.

15. Dempsey JA and Wagner PD. Exercise-induced arterial hypoxemia. J Appl Physiol 87: 1997-2006, 1999.

16. Drinkwater BL, Horvath SM, and Wells CL. Aerobic power of females, ages 10 to 68. J Gerontol 30: 385-394, 1975.

17. Echazarreta AL, Dahlen B, Garcia G, Agusti C, Barbera JA, Roca J, Dahlen SE, and Rodriguez-Roisin R. Pulmonary gas exchange and sputum cellular responses to inhaled leukotriene $\mathrm{D}_{4}$ in asthma. Am J Respir Crit Care Med 164: 202-206, 2001.

18. Echazarreta AL, Gomez FP, Ribas J, Sala E, Barbera JA, Roca J, and Rodriguez-Roisin R. Pulmonary gas exchange responses to histamine and methacholine challenges in mild asthma. Eur Respir J 17: 609-614, 2001.

19. Feisal KA and Fuleihan FJ. Pulmonary gas exchange during exercise in young asthmatic patients. Thorax 34: 393-396, 1979.

20. Forster HV, Dunning MB, Lowry TF, Erickson BK, Forster MA, Pan LG, Brice AG, and Effros RM. Effect of asthma and ventilatory loading on arterial $\mathrm{PCO}_{2}$ of humans during submaximal exercise. J Appl Physiol 75: 1385-1394, 1993.

21. Frank NR, Mead J, and Ferris BG. The mechanical behavior of the lungs in healthy elderly persons. J Clin Invest 36: 1680-1687, 1957.

22. Fry DL, Ebert RV, Stead WM, and Brown CC. The mechanics of pulmonary ventilation in normal subjects and in patients with emphysema. Am J Med 16: 80-97, 1954.

23. Gauvreau GM, Ronnen GM, Watson RM, and O'Byrne PM. Exerciseinduced bronchoconstriction does not cause eosinophilic airway inflammation or airway hyperresponsiveness in subjects with asthma. Am J Respir Crit Care Med 162: 1302-1307, 2000.

24. Graff-Lonnevig V, Bevegard S, and Eriksson BO. Ventilation and pulmonary gas exchange at rest and during exercise in boys with bronchial asthma. Eur J Respir Dis 61: 357-366, 1980.

26. Harms CA and Stager JM. Low chemoresponsiveness and inadequate hyperventilation contribute to exercise-induced hypoxemia. J Appl Physiol 79: 575-580, 1995.

27. Haverkamp HC, Dempsey JA, Miller JD, Romer LM, Pegelow DF, Lovering AT, and Eldridge MW. Repeat exercise normalizes the gasexchange impairment induced by a previous exercise bout in asthmatic subjects. J Appl Physiol. 99: 1846-1855, 2005.

28. Haynes RL, Ingram RH, and McFadden ER. An assessment of the pulmonary response to exercise in asthma and an analysis of the factors influencing it. Am Rev Respir Dis 114: 739-752, 1976.

29. Hopkins SR, Gavin TP, Siafakas NM, Haseler LJ, Olfert IM, Wagner $\mathbf{H}$, and Wagner PD. Effect of prolonged, heavy exercise on pulmonary gas exchange in athletes. $J$ Appl Physiol 85: 1523-1532, 1998.

30. Hopkins SR and Harms CA. Gender and pulmonary gas exchange during exercise. Exerc Sport Sci Rev 32: 50-56, 2004.

31. Jarjour NN and Calhoun WJ. Exercise-induced asthma is not associated with mast cell activation or airway inflammation. J Allergy Clin Immunol 89: 60-68, 1992.

32. Johnson BD, Reddan WG, Pegelow DF, Seow KC, and Dempsey JA. Flow limitation and regulation of functional residual capacity during exercise in a physically active aging population. Am Rev Respir Dis 143: 960-967, 1991.

33. Johnson BD, Saupe KW, and Dempsey JA. Mechanical constraints on exercise hyperpnea in endurance athletes. J Appl Physiol 73: 874-886, 1992.

34. Johnson BD, Scanlon PD, and Beck KC. Regulation of ventilatory capacity during exercise in asthmatics. J Appl Physiol 79: 892-901, 1995.

35. Katz RM, Whipp BJ, Heimlich EM, and Wasserman K. Exerciseinduced bronchospasm, ventilation, and blood gases in asthmatic children. J Allergy 47: 148-158, 1971.

36. Kivity S, Argaman A, Onn A, Shwartz Y, Man A, Greif J, and Fireman E. Eosinophil influx into the airways in patients with exerciseinduced asthma. Respir Med 94: 1200-1205, 2000.
37. Knudson RJ, Lebowitz MD, Holberg CJ, and Burrows B. Changes in the normal maximal expiratory flow-volume curve with growth and aging. Am Rev Respir Dis 127: 725-734, 1983.

38. Knudson RJ, Kaltenborn WT, Knudson DE, and Burrows B. The single-breath carbon monoxide diffusing capacity: reference equations derived from a healthy nonsmoking population and effects of hematocrit. Am Rev Respir Dis 135: 805-811, 1987.

39. Mansfield L, McDonnell J, Morgan W, and Souhrada JF. Airway response in asthmatic children during and after exercise. Respiration 38: 135-143, 1979.

40. McClaran SR, Harms CA, Pegelow DF, and Dempsey JA. Smaller lungs in women affect exercise hyperpnea. J Appl Physiol 84: 1872-1881, 1998

41. McClaran SR, Wetter TJ, Pegelow DF, and Dempsey JA. Role of expiratory flow limitation in determining lung volumes and ventilation during exercise. J Appl Physiol 86: 1357-1366, 1999.

42. Mead J and Whittenberger JL. Physical properties of human lungs measured during spontaneous respiration. J Appl Physiol 5: 779-796, 1953.

43. Nagakura T, Obata T, Shichijo K, Matsuda S, Sigimoto H, Yamashita $\mathbf{K}$, Masaki T, and Maekawa K. GC/MS analysis of urinary excretion of $9 \alpha, 11 \beta-\mathrm{PGF}_{2}$ in acute and exercise-induced asthma in children. Clin Exp Allergy 28: 181-186, 1998.

43a.National Asthma Education Program Expert Panel. Guidelines for the diagnosis, and management of asthma: National Heart, Lung, and Blood Institute, National Asthma Education Program Expert Panel Report. J Allergy Clin Immunol 88: 427-438, 1991.

44. O'Donnell DE, D'Arsigny C, Fitzpatrick M, and Webb KA. Exercise hypercapnia in advanced chronic obstructive pulmonary disease: the role of lung hyperinflation. Am J Respir Crit Care Med 166: 663-668, 2002.

45. Ogilvie CM, Forster RE, Blakemore WS, and Morton JW. A standardized breath holding technique for the clinical measurement of the diffusing capacity of the lung for carbon monoxide. J Clin Invest 36: 1-17, 1957.

46. O'Sullivan S, Roquet A, Dahlen B, Larsen F, Eklund A, Kumlin M, O'Byrne PM, and Dahlen SE. Evidence for mast cell activation during exercise-induced bronchoconstriction. Eur Respir J 12: 345-350, 1998.

47. Rodman JR, Haverkamp HC, Gordon SM, and Dempsey JA. Cardiovascular and respiratory system responses and limitations to exercise. In: Progress in Respiratory Research: Clinical Exercise Testing, edited by Weisman IM and Zeballos RJ. New York: Karger, 2002.

48. Ruppel G. Manual of Pulmonary Function Testing. St. Louis, MO: Mosby, 1986.

49. Sixt R, Bake B, and Oxhoj H. The single-breath $\mathrm{N}_{2}$ test and spirometry in healthy non-smoking males. Eur J Respir Dis 65: 296-304, 1984.

50. St. Croix CM, Wetter TJ, Pegelow DF, Meyer KC, and Dempsey JA. Assessment of nitric oxide formation during exercise. Am J Respir Crit Care Med 159: 1125-1133, 1999.

51. Stirling DR, Cotton DJ, Graham BL, Hodgson WC, Cockcroft DW, and Dosman JA. Characteristics of airway tone during exercise in patients with asthma. J Appl Physiol 54: 934-942, 1983.

52. Suman OE, Babcock MA, Pegelow DF, Jarjour NN, and Reddan WG. Airway obstruction during exercise in asthma. Am J Respir Crit Care Med 152: $24-31,1995$

53. Suman OE, Beck KC, Babcock MA, Pegelow DF, and Reddan WG. Airway obstruction during exercise and isocapnic hyperventilation in asthmatic subjects. J Appl Physiol 87: 1107-1113, 1999.

54. Wagner PD, Hedenstierna G, and Rodriguez-Roisin R. Gas exchange, expiratory flow obstruction and the clinical spectrum of asthma. Eur Respir J 9: 1278-1282, 1996.

55. Wardlaw AJ, Brightling CE, Green R, Woltmann G, Bradding P, and Pavord ID. New insights into the relationship between airway inflammation and asthma. Clin Sci (Lond) 103: 201-211, 2002.

56. Wasserman K, Van Kessel AL, and Burton GG. Interaction of physiological mechanisms during exercise. J Appl Physiol 22: 71-85, 1967.

57. Wetter TJ, St. Croix CM, Pegelow DF, Sonetti DA, and Dempsey JA. Effects of exhaustive endurance exercise on pulmonary gas exchange and airway function in women. J Appl Physiol 91: 847-858, 2001.

58. Wetter TJ, Xiang Z, Sonetti DA, Haverkamp HC, Rice AJ, Abbasi AA, Meyer KC, and Dempsey JA. Role of lung inflammatory mediators as a cause of exercise-induced arterial hypoxemia in young athletes. $J$ Appl Physiol 93: 116-126, 2002. 